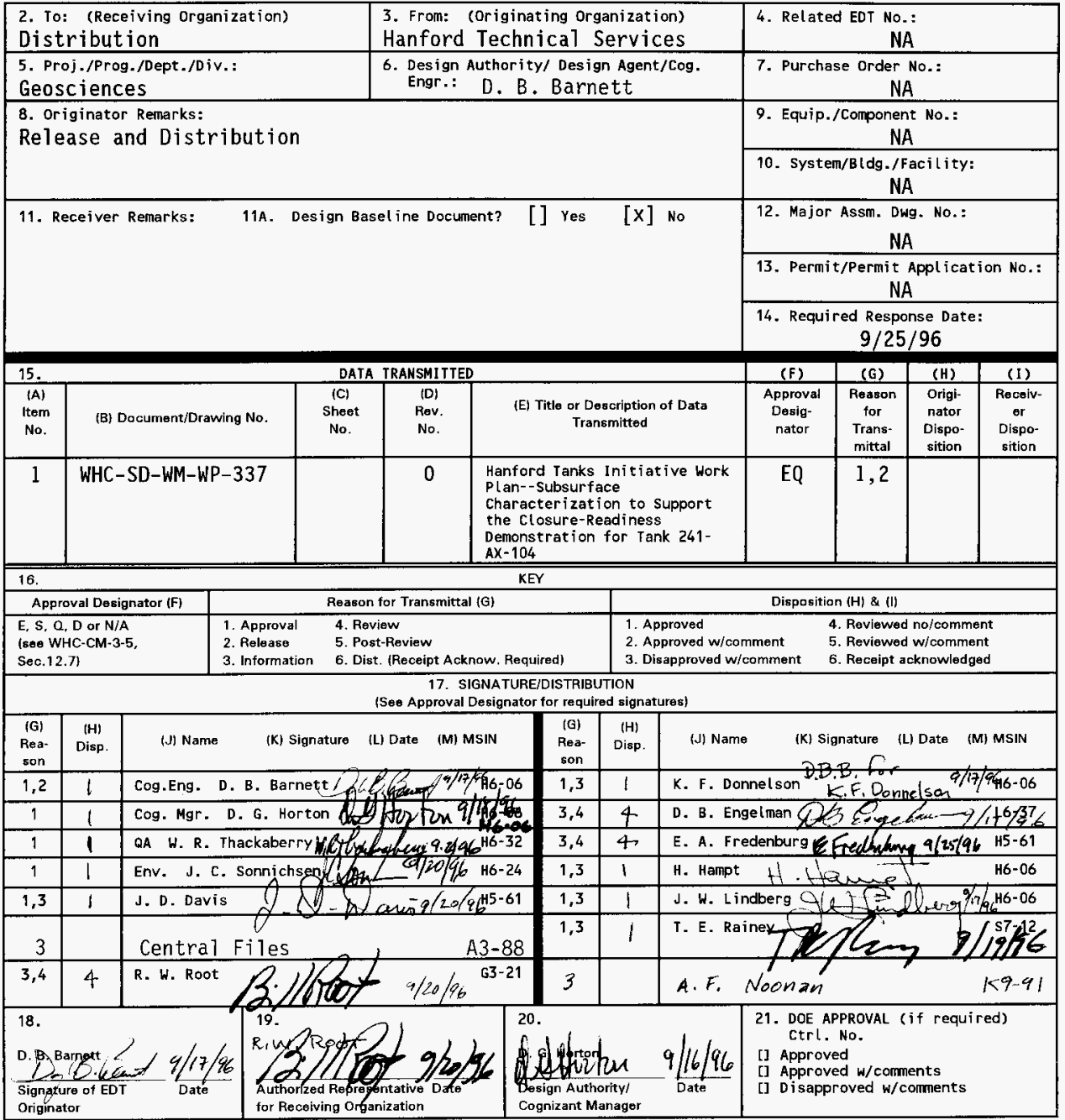

BD $-7400-172-2(05 / 96)$ GEF097 


\section{Hanford Tanks Initiative Work Plan -- Subsurface Characterization to Support the Closure-Readiness Demonstration for Tank 241-AX-104}

D. B. Barnett, J. D. Davis, H. Hampt, J. W. Lindberg, K. F. Donnelson West inghouse Hanford Company, Richland, WA 99352

U.S. Department of Energy Contract DE-AC06-87RL10930

$\begin{array}{llll}\text { EDT/ECN: } & 615779 & \text { UC: } 630 \\ \text { Org Code: } & 8 H 200 & \text { Charge Code: } & \text { R4069 } \\ \text { B\&R Code: } & \text { EW3120100 } & \text { Tota1 Pages: } & 56\end{array}$

Key Words: 241-AX Single-Shell Tank farm, vadose zone, drilling, soil properties, groundwater.

Abstract: This document presents a plan for subsurface investigation near 241-AX-104 Single-Shell tank. Objectives of the investigation are soil sampling and analyses (physical and chemical), local stratigraphic correlation, groundwater background characterization, and geophysical surveys. The primary purpose of the investigation is to supply physcial and hydraulic properties for numerical modeling of vadose zone flow and transport.

TRADEMARK DISCLAIMER. Reference herein to any specific commercial product, process, or service by trade name, trademark, manufacturer, or otherwise, does not necessarily constitute or imply its endorsement, recommendation, or favoring by the United states Government or any agency thereof or its contractors or subcontractors.

Printed in the United States of America. To obtain copies of this document, contact: WHC/BCS Document Control Services, P.O. Box 1970, Mailstop H6-08, Richland WA 99352, Phone (509) 372-2420; Fax (509) 376-4989.
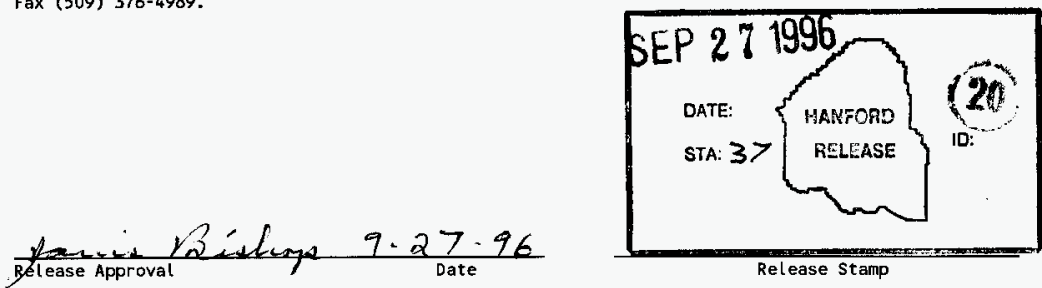

Release Stamp 
WHC-SD-WM-WP-337, Rev. 0

-- HANFORD TANKS INITIATIVE WORK PLAN --

\section{SUBSURFACE CHARACTERIZATION TO SUPPORT THE CLOSURE-READINESS DEMONSTRATION FOR TANK 241-AX-104}


WHC-SD-WM-WP-337, Rev. 0

\section{CONTENTS}

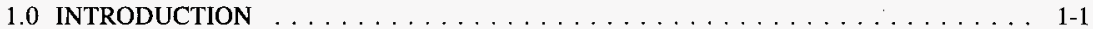

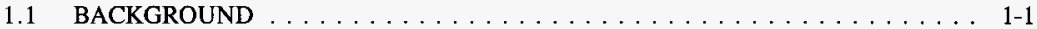

1.2 DATA NEEDED TO MEET REGULATORY REQUIREMENTS . . . . . . . . . 1-5

1.3 OBJECTIVES AND SCOPE OF SUBSURFACE CHARACTERIZATION

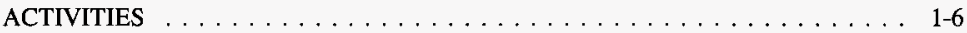

2.0 PREVIOUS WORK AND SUMMARY OF AVAILABLE INFORMATION $\ldots \ldots \ldots \ldots$. . .

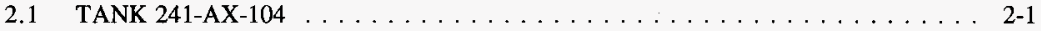

2.2 GEOLOGIC SETTING OF THE HANFORD SITE AND 200 EAST AREA $\ldots \ldots$ 2-1

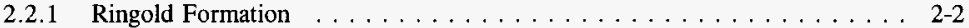

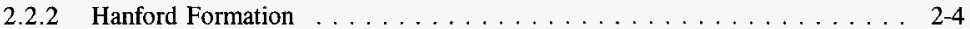

2.2.3 Holocene Surficial Deposits . . . . . . . . . . . . . . . . . 2-4

2.2.4 Vadose Zone Geology of the 241-AX Tank Farm . . . . . . . . . . . . 2-4

2.3 HYDROLOGY . . . . . . . . . . . . . . . . . . . . . . . . . 2-9

2.3.1 Saturated Zone . . . . . . . . . . . . . . . . . . . . . . 2-9

2.3 .2 Unsaturated Zone . . . . . . . . . . . . . . . . . . . . 2-10

2.4 VADOSE ZONE AND GROUNDWATER CONTAMINATION . . . . . . . . . 2-10

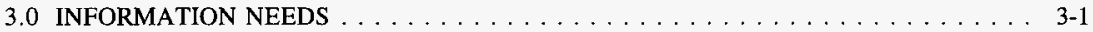

3.1 UNRESOLVED SINGLE-SHELL TANK CLOSURE ISSUES $\ldots \ldots \ldots \ldots \ldots$. . . . 3-1

3.2 TECHNICAL APPROACH TO ISSUE RESOLUTION $\ldots \ldots \ldots \ldots \ldots \ldots \ldots . \ldots 3-2$

3.2 .1 Identifying Scope of Data Needs . . . . . . . . . . . . . . . 3-3

3.2.2 Evaluating Adequacy of Existing Data $\ldots \ldots \ldots \ldots \ldots \ldots \ldots$

3.2 .3 Identifying Data Needs . . . . . . . . . . . . . . . . . . 3-3

3.2.4 Selecting Methods for Collecting Additional Data . . . . . . . . . 3-3

3.2.5 Ensuring Methods and Additional Data Fulfill Needs (Data Quality

Objectives) . . . . . . . . . . . . . . . . . . . 3-4

3.2.6 Implementing Data Collection and Analysis . . . . . . . . . . 3-4

4.0 TASK DESCRIPTIONS . . . . . . . . . . . . . . . . . . . . . . 4-1

4.1 BOREHOLE DRILLING AND WELL CONSTRUCTION . . . . . . . . . . 4-1

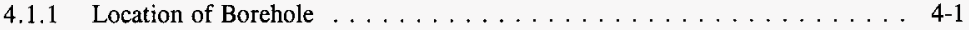

4.1 .2 Borehole Drilling . . . . . . . . . . . . . . . . 4 4

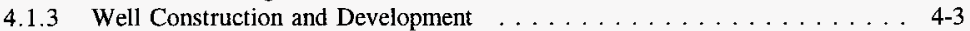

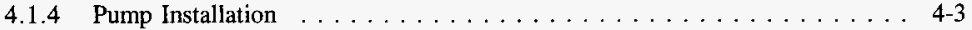

4.2 LITHOLOGIC LOGGING . . . . . . . . . . . . . . . . . . . . . . . . 4-5

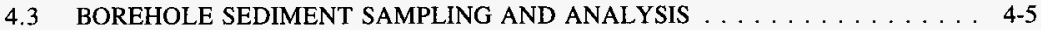

4.3 .1 Sampling Intervals $\ldots \ldots \ldots \ldots \ldots \ldots \ldots \ldots \ldots \ldots$

4.3 .2 Sediment Analysis . . . . . . . . . . . . . . . . . . . . . 4-6

4.4 GEOPHYSICAL LOGGING $\ldots \ldots \ldots \ldots \ldots \ldots \ldots \ldots \ldots$

4.5 DYNAMIC HYDRAULIC TESTING AND FLOWMETER SURVEY . . . . . . . 4-9

4.6 GROUNDWATER SAMPLING AND ANALYSIS $\ldots \ldots \ldots \ldots \ldots \ldots \ldots$

4.6 .1 Well Purging ... . . . . . . . . . . . . . . . . . 4-10

4.6 .2 Groundwater Sampling . . . . . . . . . . . . . . . 4-10

4.6 .3 Groundwater Analysis . . . . . . . . . . . . . . . . 4-11

4.6.4 Constituent List and Groundwater Sampling Schedule . . . . . . . . . . 4-11 


\section{CONTENTS (Continued)}

5.0 GENERAL GUIDANCE DOCUMENTATION AND PROJECT MANAGEMENT $\ldots \ldots$. $5-1$

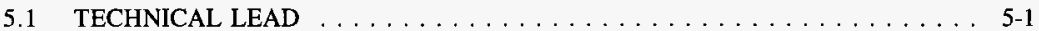

5.2 QUALITY CONTROL AND QUALITY ASSURANCE ENGINEERS . . . . . . 5-1

5.3 FIELD TEAM LEADER $\ldots \ldots \ldots \ldots \ldots \ldots \ldots \ldots \ldots \ldots \ldots \ldots$

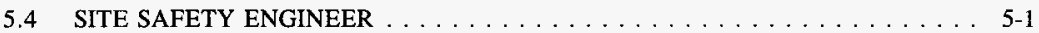

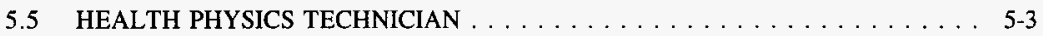

5.6 CONSTRUCTION AND DESIGN ENGINEER $\ldots \ldots \ldots \ldots \ldots \ldots \ldots \ldots$

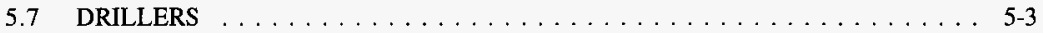

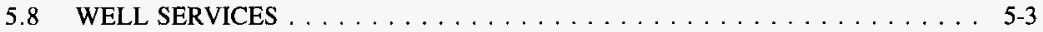

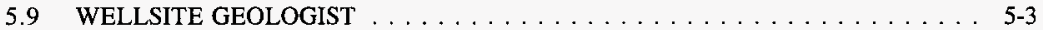

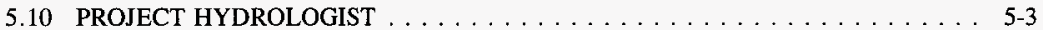

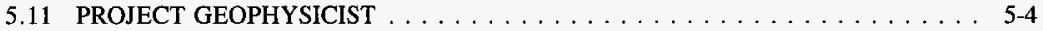

5.12 SAMPLING AND MOBILE LABORATORY $\ldots \ldots \ldots \ldots \ldots \ldots \ldots$

5.13 SAMPLE DATA AND LABORATORY ADMINISTRATION $\ldots \ldots \ldots \ldots \ldots$

5.14 ANALYTICAL CHEMISTRY LABORATORY $\ldots \ldots \ldots \ldots \ldots \ldots \ldots \ldots$

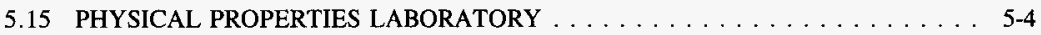

5.16 WORK PLAN CHANGES $\ldots \ldots \ldots \ldots \ldots \ldots \ldots \ldots \ldots \ldots \ldots$

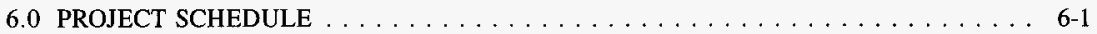

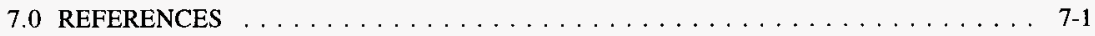

\section{FIGURES:}

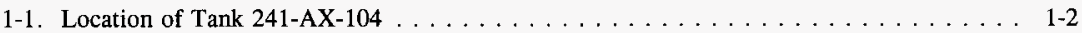

1-2. Interior of Tank $241-\mathrm{AX}-104$, Showing Current Condition after Sluicing $\ldots \ldots \ldots$ 1-3

2-1. Suprabasalt Stratigraphic Units . . . . . . . . . . . . . . . . . . 2-3

2-2. General Vadose Zone Geology Beneath 241-A and 241-AX Tank Farms . . . . . . . 2-6

2-3. Geologic Cross Section Through the 241-AX Tank Farm Showing Distribution of

Vadose Zone Geologic Units . . . . . . . . . . . . . . . . . . . . . . 2-7

2-4. Wells and Cross Section Location Map . . . . . . . . . . . . . . . . . . . 2-8

2-5. Water Table Map for the 200 East Area, June $1995 \ldots \ldots \ldots$. . . . . . . . . 2-11

4-1. Primary and Alternate Borehole Locations . . . . . . . . . . . . . . . . 4-2

4-2. Well Construction Diagram and Lithologic Sample Locations . . . . . . . . . . . . . 4-4

5-1. Project Management Structure and Lines of Communication . . . . . . . . . . . 5-2

$6-1$. Project Schedule . . . . . . . . . . . . . . . . . . . . . . 6-2

\section{TABLES:}

4-1. Sediment Physical Properties and Test Methods . . . . . . . . . . . . . . 4-7

4-2. Sediment Chemistry and Test Methods . . . . . . . . . . . . . . . . . 4-8

4-3. Sediment Leachate Analyses and Test Methods . . . . . . . . . . . . . . . . . . 4-9

4-3. Appendix IX Analytical Methods and Constituent List for Groundwater Analyses . . . . . 4-12

4-4. Supplemental Constituent List for Groundwater Analyses . . . . . . . . . . . . . 4-16 


\section{ACRONYMS}

$\begin{array}{ll}\text { ASA } & \text { American Society of Agronomy } \\ \text { ASTM } & \text { American Society of Testing and Materials } \\ \text { CRBG } & \text { Columbia River Basalt Group } \\ \text { DOE } & \text { U.S. Department of Energy } \\ \text { DQO } & \text { data quality objective } \\ \text { Ecology } & \text { Washington State Department of Ecology } \\ \text { EII } & \text { environmental investigations instructions } \\ \text { EPA } & \text { U.S. Environmental Protection Agency } \\ \text { GSFR } & \text { Groundwater Sample Field Record } \\ \text { HTI } & \text { Hanford Tanks Initiative } \\ \text { HWOP } & \text { Hazardous Waste Operations Permit } \\ \text { ICF KH } & \text { ICF Kaiser Hanford } \\ \text { ICP } & \text { inductively coupled plasma } \\ \text { NEPA } & \text { National Environmental Policy Act } \\ \text { PUREX } & \text { plutonium-uranium extraction } \\ \text { RCRA } & \text { Resource Conservation and Recovery Act of 1976 } \\ \text { SAF } & \text { Sample Authorization Form } \\ \text { SDLA } & \text { Sample Data and Laboratory Administration } \\ \text { SST } & \text { single-shell tank } \\ \text { SSTCWP } & \text { Single-Shell Tank Closure Work Plan } \\ \text { Tri-Party } & \\ \text { Agreement } & \text { Hanford Federal Facility Agreement and Consent Order } \\ \text { TWRS } & \text { Tank Waste Remediation System } \\ \text { WAC } & \text { Washington Administrative Code } \\ \text { WHC } & \text { Westinghouse Hanford Company } \\ \text { WMA } & \text { waste management area }\end{array}$


WHC-SD-WM-WP-337, Rev. 0 


\subsection{INTRODUCTION}

This work plan defines the subsurface characterization activities that will be completed to help achieve the objectives of the Hanford Tanks Initiative (HTI) project for Tank 241-AX-104. Included in the work plan are (1) a summary of currently available information, (2) an analysis of the needs for additional information, (3) descriptions of field and laboratory tasks, (4) project management structure, and (5) a projected schedule for field and laboratory tasks.

\subsection{BACKGROUND}

The HTI is a 4-year project resulting from the technical and financial partnership of the U.S. Department of Energy (DOE) Offices of Waste Management and Science and Technology Development. HTI project activities will begin in FY 1997 and focus on two high-level waste tanks at the Hanford Site (tanks 241-AX-104 and 241-C-106).

The objective of the HTI project is to support the mission of the Tank Waste Remediation System (TWRS) (Knutson 1995) by:

(1) Accelerating demonstration of the ability to retrieve consolidated "hard-heel" waste residue in Tank 241-C-106 after most waste has been removed by sluicing.

(2) Providing a basis -- through technology applications, performance analyses, and risk assessments -- for establishing an acceptable approach to defining an end-state condition for tank farm closure.

(3) Applying technologies, methods, and processes to measure compliance with performance criteria for waste retrieval and tank closure.

To achieve the second and third objectives, the focus will be on Tank 241-AX-104 (Figure 1-1). The HTI selected Tank 241-AX-104 to evaluate closure readiness because waste previously was sluiced from the tank as part of strontium and cesium recovery operations in the early 1970's. The small amount of waste remaining in the tank (Figure 1-2) may already approximate the interim retrieval goal of the Hanford Federal Facility Agreement and Consent Order (Tri-Party Agreement) (Washington State Department of Ecology [Ecology] et al. 1994) to retrieve $\geq 99 \%$ of the waste in high-level waste tanks. For 100 -Series tanks with million-gallon capacities such as Tank 241-AX-104, achieving this goal would mean that $\leq 10.2 \mathrm{~m}^{3}\left(\leq 360 \mathrm{ft}^{3}\right)$ of waste could potentially remain in the tank.

If sediments in the 241-AX Tank Farm have been contaminated from tank leaks to the extent that soil removal is required to close the tank, tank farm, or operable unit, that circumstance could necessitate removal of Tank 241-AX-104 and/or other tanks in the 241-AX Tank Farm. If required, tank removal would entail the retrieval of residual waste from Tank 241-AX-104. Consequently, contaminant transport modeling in support of closure decisions must consider the volume and properties of the residual waste in Tank $241-\mathrm{AX}-104$, sediment physical properties affecting contaminant transport, and potential contamination residing in the sediments from past leaks and retrieval operations. 
WHC-SD-WM-WP-337, Rev. 0

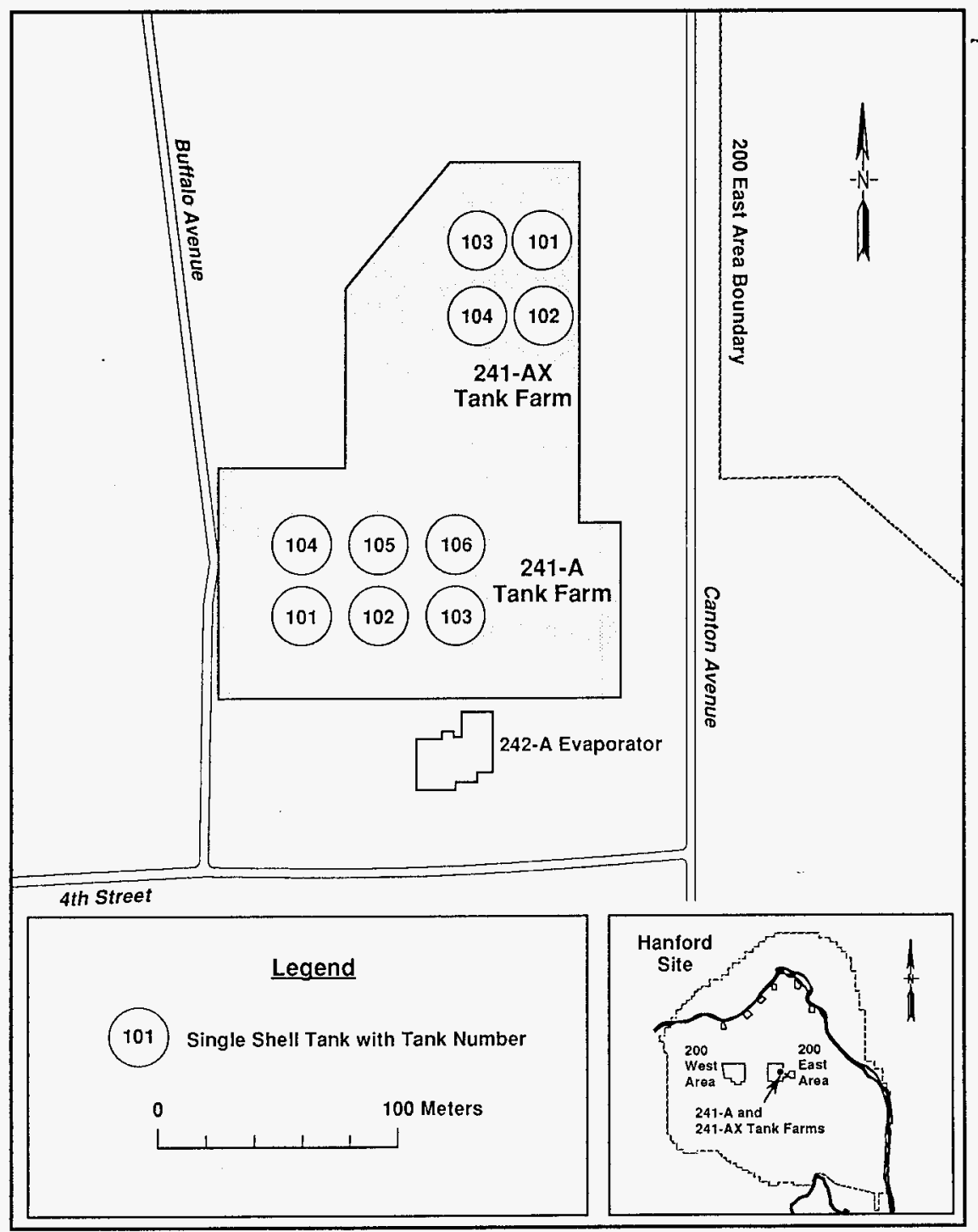

H96010183.4

Figure 1-1. Location of Tank 241-AX-104. 


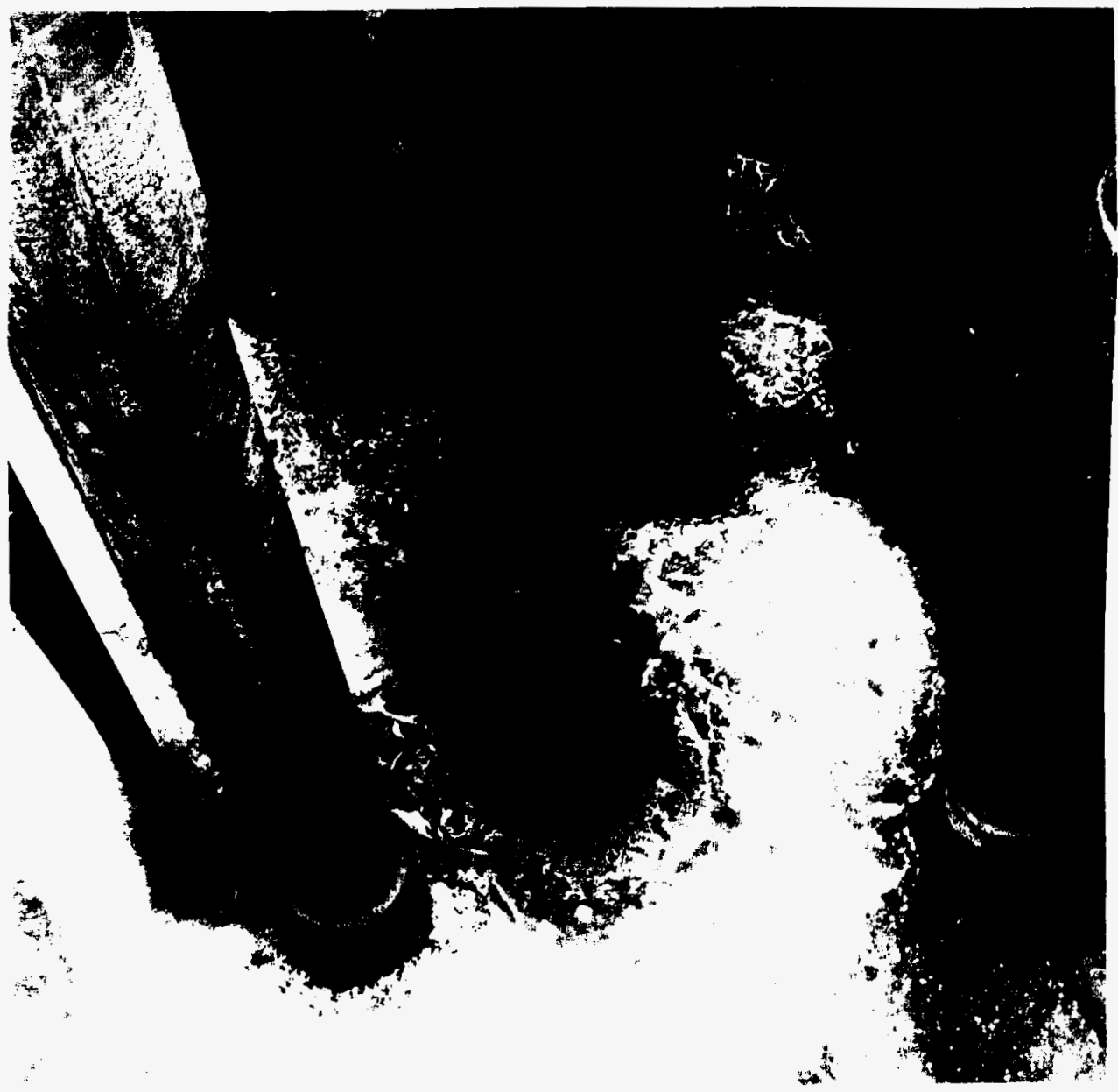

Figure 1-2. Interior of Tank 241-AX-104, Showing Current Condition after Sluicing. 
WHC-SD-WM-WP-337, Rev. 0

This page intentionally left blank. 
WHC-SD-WM-WP-337, Rev. 0 following:

Activities planned for the closure-readiness assessment for Tank 241-AX-104 include the

(1) Determine the site-specific flow and contaminant transport properties of vadose zone sediments between Tank 241-AX-104 and the water table, and groundwater hydrology beneath the tank.

(2) Characterize waste leaked from the tank to the tank backfill and vadose zone sediments.

(3) Complete detailed photography of in-tank waste. Deploy a topographic mapping system to assist with measurement of residual waste thickness, distribution and volume, and the light-duty utility arm and other technologies as required to obtain waste samples for laboratory characterization.

(4) Assess, based on the amount and distribution of waste residue associated with the tank and the site-specific hydraulic properties of the vadose zone sediments, whether the tank, when configured for permanent closure, will comply with closure criteria.

\subsection{DATA NEEDED TO MEET REGULATORY REQUIREMENTS}

To comply with DOE Order 5820.2A and Washington Administrative Code (WAC) 173-303 regulations, it will be necessary to demonstrate, through credible predictions of contaminant transport from residual waste, that the closure of Tank 241-AX-104 will not cause unacceptable long-term risk to the public. Specific data and information needed to predict contaminant transport and assess risk have been identified based on (1) the input requirements of technical software that will be used to numerically simulate contaminant transport processes, and (2) the requirements of similar analyses previously completed for other Hanford Site projects and facilities (e.g., see Davis and Delaney [1992]).

Several single-shell tank (SST) closure issues have been identified (DOE-RL 1996b) that relate directly to the need to characterize subsurface hydrogeologic properties for the 241-AX Tank Farm. The SST closure issues pertinent to this work plan are summarized in Section 3.1. In addition to issues resolution, contaminant transport analyses and long-term risk assessments will be applied by the HTI to:

- Focus resources for waste characterization and closure engineering development

- Evaluate and compare SST-tank closure engineering alternatives

- Support SST-tank closure decision-making and closure permit application.

Sensitivity analyses (i.e., determining the sensitivity of analytical results to variations in input parameters) based on numerical modeling are being used to evaluate the relative importance of parameters whose values can be altered by engineered design. Consequently, the results of sensitivity analyses have been used, and will continue to be used, to focus subsurface characterization and engineering development activities identified by this work plan. Demonstration of the sensitivities of the various parameters will promote credible definition of tasks to fulfill regulatory requirements. 


\subsection{OBJECTIVES AND SCOPE OF SUBSURFACE CHARACTERIZATION ACTIVITIES}

The principal objective of the tasks described by this work plan is to accomplish the first of the activities listed in Section 1.1: Determine the site-specific groundwater flow and contaminant transport properties of vadose zone sediments between Tank 241-AX-104 and the water table. Related objectives include site-specific determination of the hydraulic conductivity of sediments comprising the upper part of the uppermost aquifer, measurement of the direction and velocity of groundwater flow in the uppermost aquifer, and definition of the baseline conditions for groundwater quality and vadose zone sediment chemistry. Completing this first activity (as well as the second and third activities) is an essential prerequisite of attaining the fourth objective.

The scope of activities governed by this work plan includes the following:

- Borehole drilling adjacent to the 241-AX Tank Farm to obtain samples of the strata between the tank farm and the water table. The borehole will be drilled to sufficient depth to intercept the top $20 \mathrm{ft}$ of the uppermost aquifer

- Lithologic logging to obtain detailed stratigraphic information

- Geophysical logging to indicate major stratigraphic boundaries, the presence or absence of man-made radionuclides, and to measure vadose zone moisture content

- $\quad$ Sediment sampling during the drilling process using a split-spoon sampler

- Chemical analysis of sediment samples for potential contaminants

- Column leach tests of selected sediment intervals to determine the mobility of potential contaminants and natural sediment components

- Analysis of sediment samples by the UFA (a trademark of Beckman Instruments, Inc.) or equivalent methods to directly measure unsaturated hydraulic conductivity; related parameters will also be measured (e.g., grain size distribution, moisture content, specific gravity of coarse and fine fractions, bulk density, and porosity)

- Completion and development of the borehole as a Resource Conservation and Recovery Act (RCRA) groundwater monitoring well

- Groundwater sampling quarterly for 1 year

- Chemical analyses of groundwater samples for potential contaminants and to establish the baseline groundwater quality

- Direct measurement of groundwater flow direction and velocity and derivation of values for saturated hydraulic conductivity

- Slug testing to cross check the value for saturated hydraulic conductivity obtained by the flowmeter. 
WHC-SD-WM-WP-337, Rev. 0

\subsection{PREVIOUS WORK AND SUMMARY OF AVAILABLE INFORMATION}

\subsection{TANK 241-AX-104}

The 241-AX Tank Farm is a group of four SSTs located near the eastern edge of the 200 East Area of the Hanford Site (Figure 1-1). The 241-AX tanks were the last SST farm to be built at the Hanford Site. Each of the four tanks in the 241-AX Tank Farm is $33.83 \mathrm{~m}$ (75 ft) in diameter and has a capacity of 3,785,000 L (1 Mgal). The tanks are among the largest-capacity SSTs at the Hanford Site. The tank domes are covered by at least $1.83 \mathrm{~m}(6 \mathrm{ft})$ of soil; the tank bottoms are, at minimum, $15.77 \mathrm{~m}(51.75 \mathrm{ft}$ ) below grade (Brevick 1995). Tanks in the 241-A and 241-AX tank farms were sluiced in the early 1970 's to recover heat-producing ${ }^{90} \mathrm{Sr}$ from the sludge and ${ }^{137} \mathrm{Cs}$ from the supernatant for separate storage, to reduce waste volumes, and to remove selected SSTs from service (Rodenhizer 1987). The 241-AX tanks are currently inactive and, with the exception of Tank 241-AX-101, have undergone interim stabilization (Hanlon 1996; DOE-RL 1996b). Tank 241-AX-104 is in the southwest corner of the group.

The 241-AX-104 Tank operated from 1966 until 1976 and received high-level and low-level radioactive wastes and organic and inorganic wastes from the plutonium-uranium extraction (PUREX) and B Plant facilities. Radionuclides reported to have been formerly stored in the tank in significant quantities are ${ }^{89 / 90} \mathrm{Sr}$ and ${ }^{137} \mathrm{Cs}$. Radionuclides in minor amounts were ${ }^{125} \mathrm{Sb}$, ${ }^{154 / 155} \mathrm{Eu}$, nat-U, ${ }^{237} \mathrm{~Np}$, and ${ }^{239 / 240} \mathrm{Pu}$ (Van Vleet 1993). The tank also received high-level supernatant liquids from other nearby tanks (DOE-RL 1996a). After Tank 241-AX-104 was sluiced, it was determined in 1977 to have leaked $30,280 \mathrm{~L}(\sim 8,000 \mathrm{gal})$ and was removed from further service. Interim isolation and stabilization were completed in December 1982 (Brevick 1995).

Tank 241-AX-104 is surrounded by eight shallow vadose zone monitoring wells (drywells) that are used regularly to monitor radiation in the subsurface. Based on data from one of these drywells, an occurrence report was issued in 1976 . The increased radioactivity in the drywell was attributed to downward migration of contamination from a vapor header leak identified in April 1975 (DOE-RL 1996b).

The 241-A and 241-AX tank farms are currently part of the RCRA Waste Management Area (WMA) A-AX (Caggiano and Goodwin 1991) and within the 200-PO-3 source operable unit and 200-PO-1 groundwater operable unit, respectively. Groundwater monitoring is conducted on a semiannual basis to comply with RCRA "interim-status, contamination-indicator-parameter-evaluation" provisions. Contamination indicator parameters are $\mathrm{pH}$, total organic halogen, total organic carbon, and specific conductance. Critical mean values for these four parameters have not been exceeded thus far in RCRA groundwater monitoring at the A-AX WMA (Caggiano 1996). Groundwater contamination in the vicinity of the 241-AX-104 Tank is discussed further in Section 2.4.

\subsection{GEOLOGIC SETTING OF THE HANFORD SITE AND 200 EAST AREA}

The geology of the Hanford Site is described in detail in DOE (1988), Delaney et al. (1991), Reidel et al. (1992), and Lindsey et al. (1994a,b). This section summarizes information described in those reports relevant to the 200 East Area.

The Hanford Site is underlain by a thick sequence of tholeiitic basalt flows called the Columbia River Basalt Group (CRBG) and thin continental sedimentary deposits. Folding and 
faulting of these rocks over the past 17 million years has created broad structural and topographic basins separated by asymmetric anticlinal ridges. The Hanford Site lies within one of the larger basins, the Pasco Basin. The Pasco Basin is bounded on the north by the Saddle Mountains and on the south by Rattlesnake Mountain and the Rattlesnake Hills, and is divided into a series of east-west trending synclines by the Yakima Ridge and Umtanum Ridge anticlines. The largest syncline, the Cold Creek syncline, lies between Umtanum Ridge and Yakima Ridge and is the principal structure containing the DOE WMAs, including the 200 East Area and the 241-AX Tank Farm.

Overlying the CRBG at the Hanford Site are up to $220 \mathrm{~m}(722 \mathrm{ft})$ of the late Miocene, Pliocene, and Pleistocene suprabasalt sediment. The principal suprabasalt stratigraphic units underlying the Hanford Site are, in ascending order, the Ringold Formation (Miocene-Pliocene), Plio-Pleistocene unit (late Pliocene to early Pleistocene), and the Hanford formation (Pleistocene) (Figure 2-1). Of these, the Plio-Pleistocene unit is not found beneath the 200 East Area, where the 241-AX Tank Farm is located. A regionally discontinuous veneer of recent alluvium, colluvium, and/or eolian sediments overlies the principal geologic units. Backfill is common at and adjacent to numerous Hanford facilities, especially the tank farms. The following sections describe the various stratigraphic units found within the Hanford Site 200 East Area.

\subsubsection{Ringold Formation}

The Ringold Formation, described in detail in Lindsey (1995), consists of a heterogeneous mix of variably cemented and compacted gravel, sand, silt, and clay. Ringold strata are described on the basis of sediment types or facies associations (Reidel et al. 1992; Lindsey et al. 1994a,b; Lindsey 1991, 1995). Ringold Formation facies associations consist of fluvial gravel-dominated deposits (facies association I), fluvial sand-dominated deposits (facies association II), paleosols and overbank deposits (facies association III), lacustrine deposits (facies association IV), and alluvial fanglomerate (facies association V). Ringold strata are grouped into three informal members defined on the basis of dominant facies associations: (1) the member of Wooded Island (facies association I, II, III, and IV), (2) the member of Taylor Flat (facies association II and III), and (3) the member of Savage Island (facies association IV) (Lindsey 1995). The member of Wooded Island is further subdivided into informal units defined by the presence of widespread fluvial gravel and referred to as units A, B, C, D, and E (Reidel et al. 1992; Lindsey et al. 1994a,b; Lindsey 1995). A widespread lacustrine dominated interval, referred to as the lower mud unit, also occurs near the base of the Wooded Island member (Reidel et al. 1992; Lindsey et al. 1994a,b; Lindsey 1995).

Beneath the 200 East Area, the Ringold Formation is thin or absent. Where present, only unit $A$, the lower mud unit, and unit $E$ (all of the member of Wooded Island) are found. In addition, these units may only occur as the erosional remnants where they are encountered. Detailed descriptions of the Ringold Formation beneath the 200 East Area are found in Connelly et al. (1992a), Lindberg et al. (1992), Lindsey et al. (1992, 1994a,b), and Lindsey (1995). 


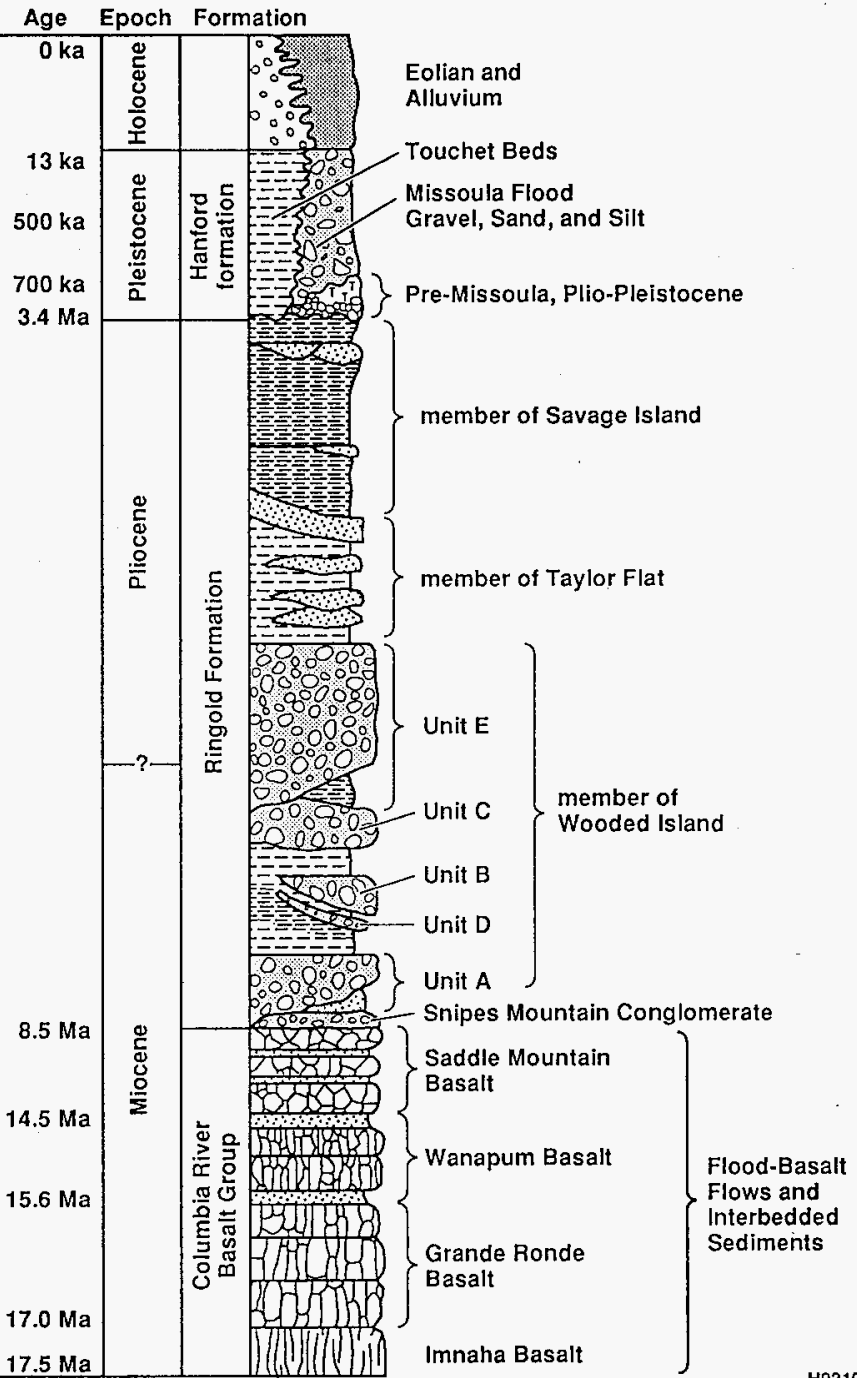

H9210011.1b

Figure 2-1. Suprabasalt Stratigraphic Units. 


\subsubsection{Hanford Formation}

The Hanford formation is an informal name applied to terrigenous clastic sediments displaying distinctive physical properties attributed to deposition by Pleistocene ( 2 million years to 10,000 years) cataclysmic floods (Baker at al. 1991). Evidence has been found for at least four major cataclysmic flood sequences in and around the Hanford Site (Baker et al. 1991). The Hanford

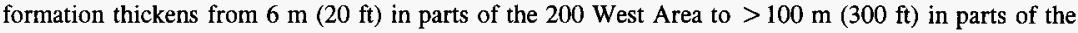
200 East Area.

Hanford formation deposits typically are divided into a variety of sediment types, facies, or lithologic packages based on grain size and sedimentary structures. Recent reports on the Hanford formation (Reidel et al. 1992; Lindsey et al. 1994a,b) recognize three basic facies:

(1) gravel-dominated, (2) sand-dominated, and (3) silt-dominated. These facies generally correspond to the coarse gravels, laminated sands, and graded rhythmites or Touchet Beds, respectively, as described by DOE (1988), Baker et al. (1991), and Delaney et al. (1991).

The gravel-dominated facies consists of coarse sand and granule-to-boulder gravel displaying massive bedding, plane to low-angle bedding, and large-scale cross-bedding in outcrop. Matrix commonly is lacking from the gravel, resulting in an open-framework texture. The sand-dominated facies consists of fine- to coarse-grained sand and small pebbles that display plane lamination and bedding, and plane and trough cross-bedding in outcrop. Small pebbles and pebbly and silty interbeds ( $<20 \mathrm{~cm}[<8 \mathrm{in}$.$] thick) may be locally encountered. Where silt content is low, an open-framework$ texture can occur. The silt-dominated facies consists of planar-tabular horizons of silt and fine to coarse sand forming normally graded beds $<1 \mathrm{~m}(<3.3 \mathrm{ft})$ thick. Plane lamination and ripple cross-lamination is common in outcrop. The three facies are inter-gradational. Lenticular beds and stratigraphic pinchouts are common. In addition, discordant bodies of sand and silt, called clastic dikes, commonly cut across Hanford formation strata (Black 1979).

Hanford formation strata are locally subdivided into a series of stratigraphic units of variable thickness and lateral extent. In the 200 East Area they are referred to as unit $\mathrm{H} 1$ (consisting of gravel and lesser sand facies), unit $\mathrm{H} 2$ (consisting of sand and silt facies), and unit H3 (consisting of interbedded gravel and sand facies) (Lindsey et al. 1994a,b). Contacts between these units are not always sharp. Gradational contacts and interfingering of units are common.

\subsubsection{Holocene Surficial Deposits}

Holocene surficial deposits consisting of silt, sand, and gravel form a thin $(<5 \mathrm{~m}[<16 \mathrm{ft}])$ veneer across much of the Hanford Site. In the southern part of 200 East Area, these deposits consist dominantly of laterally discontinuous sheets of wind-blown silt and fine-grained sand. At and near Hanford facilities, backfill also is common. Backfill, such as is found at Hanford tank farms, typically is locally derived Hanford formation material.

\subsubsection{Vadose Zone Geology of the 241-AX Tank Farm}

Three wells (299-E25-13, -40 , and -41$)$ extending to depths of $\sim 91.5 \mathrm{~m}(\sim 300 \mathrm{ft})$ fully penetrate the vadose zone at or adjacent to the 241-AX Tank Farm. An additional 23 vadose zone borings (dry wells), which generally reach depths of $30.5 \mathrm{~m}(100 \mathrm{ft})$, also are at the site. Geologic data from the groundwater wells consist of lithologic descriptions, stratigraphic data, and basic 
measurements of grain size distribution and calcium carbonate content. Geologic data for the vadose zone borings consist of generalized geologic logs supplemented by grain size and calcium carbonate data in the ROCSAN database. No other physical properties data needed for vadose zone transport modeling are available for the 241-AX Tank Farm, because none of the wells at or near the 241-AX Tank Farm were drilled with detailed characterization for modeling of the vadose zone as an objective.

The following discussion of 241-AX Tank Farm vadose zone geology is based on data and interpretations from the wells at the site, as well as information and insights from Price and Fecht (1976), Caggiano and Goodwin (1991), Lindsey and Law (1993), and the ROCSAN database. Because detailed site-specific data are limited, the following discussion and interpretation is necessarily generalized. It is constrained by data and observations taken from geologic features found elsewhere that are interpreted to be analogous to those at the 241-AX Tank Farm.

The vadose zone beneath the 241-AX Tank Farm is found almost entirely within the Hanford formation. Figures 2-2 and 2-3 illustrate vadose zone stratigraphy in the vicinity of the 241-AX Tank Farm. Figure 2-4 shows the location of the cross section of Figure 2-3 and locations of wells used for stratigraphic interpretations. The vadose zone extends downwards into the uppermost few meters of the Ringold Formation. Backfill forms the uppermost part of the vadose zone.

2.2.4.1 Backfill. The base of the original 241-AX Tank Farm excavation is situated 0 to $\sim 17 \mathrm{~m}$ $(0$ to $\sim 55 \mathrm{ft})$ below grade. Backfill consists of slightly-pebbly to slightly-silty coarse to fine sand of the Hanford formation (Price and Fecht 1976) removed from the original excavation and later returned during tank construction. Available information indicates the backfill is not engineered, although it was returned to the excavation in lifts, resulting in varying degrees of compaction due to day-to-day construction activities.

2.2.4.2 Hanford Unit H1. The uppermost 3.6 to $15 \mathrm{~m}$ (12 to $50 \mathrm{ft}$ ) of undisturbed material beneath the base of the 241-AX Tank Farm consists of a westward thinning sequence of slightly-silty, pebbly, very coarse to coarse sand, and sandy fine to very fine pebble gravel, to pebbly very coarse sand (Price and Fecht 1976) assigned to units $\mathrm{H} 1$ and H1A (Figures 2-2 and 2-3). These strata are interpreted to consist of interbedded sand and gravel facies. The gravel beds generally thin to the west and south. Unit H1A corresponds to an upper sand-rich interval and unit $\mathrm{H} 1$ refers to a lower, more gravel-rich interval. Units $\mathrm{H} 1$ and $\mathrm{H} 1 \mathrm{~A}$ interfinger.

Bedding in units $\mathrm{H} 1$ and $\mathrm{H} 1 \mathrm{~A}$ is typically laterally discontinuous, with interfingering sandand gravel-rich horizons forming a complex series of tabular and wedge-shaped lenses. Grain size data, borehole log descriptions, and excavations such as described by Goldstrand (1984) suggest pebbles ( $2 \mathrm{~mm}$ to $64 \mathrm{~mm}$ [.078 to $2.5 \mathrm{in}$.]) dominate the gravel fraction. Total gravel content varies from approximately 10 to $50 \mathrm{wt} \%$ in samples from units $\mathrm{H} 1$ and $\mathrm{H} 1 \mathrm{~A}$.

There is no direct evidence of clayey horizons beneath the 241-AX Tank Farm. However, thin $(<\mathrm{l} \mathrm{m}[<3.3 \mathrm{ft}]$ ) clayey horizons have been identified in borings adjacent to the 241-AX Tank Farm. Clay lenses and laterally persistent clayey interbeds in gravel- and sand-dominated facies at the scale of the individual tank farms (tens of meters) also have been observed in outcrops around the 200 East Area (Reidel et al. 1992) and in excavations near the 241-AX Tank Farm (Goldstrand 1984). Samples with clay content in excess of $20 \mathrm{wt} \%$ also suggests the likely presence of clay beds. 
$\mathbf{A}-\mathbf{A X}$

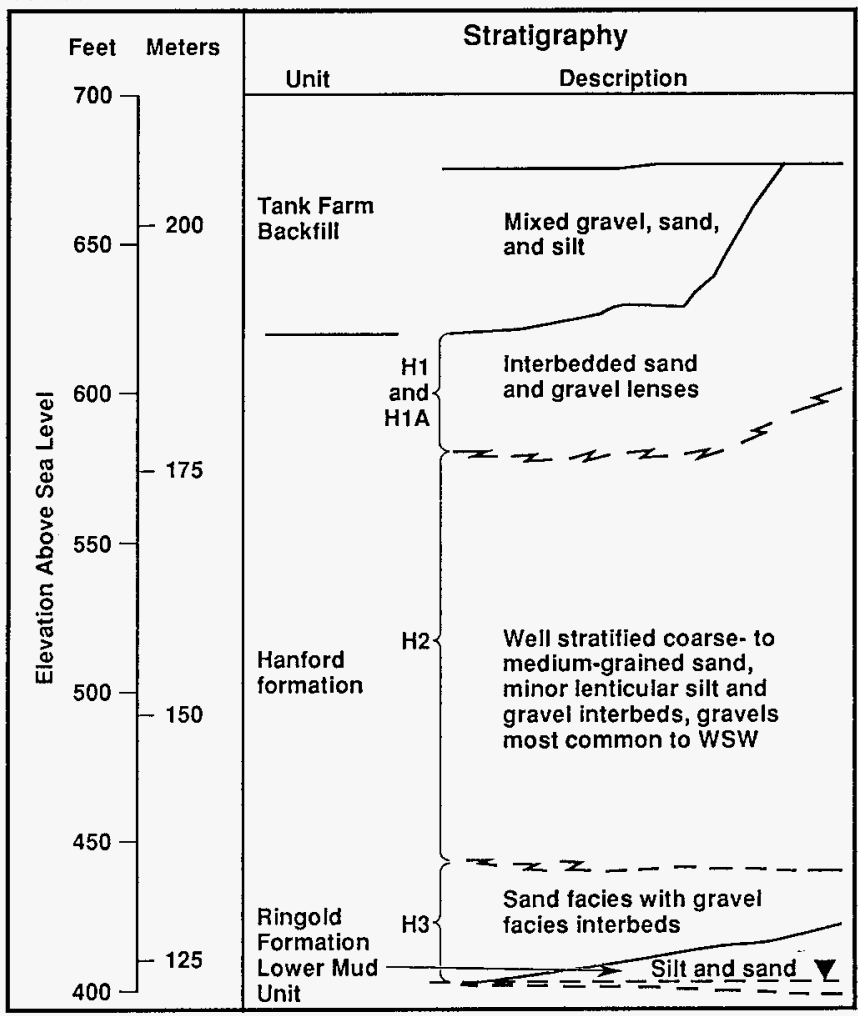

H96010075.2

Figure 2-2. General Vadose Zone Geology Beneath 241-A and 241-AX Tank Farms.

(Modified from Lindsey and Law 1993) 


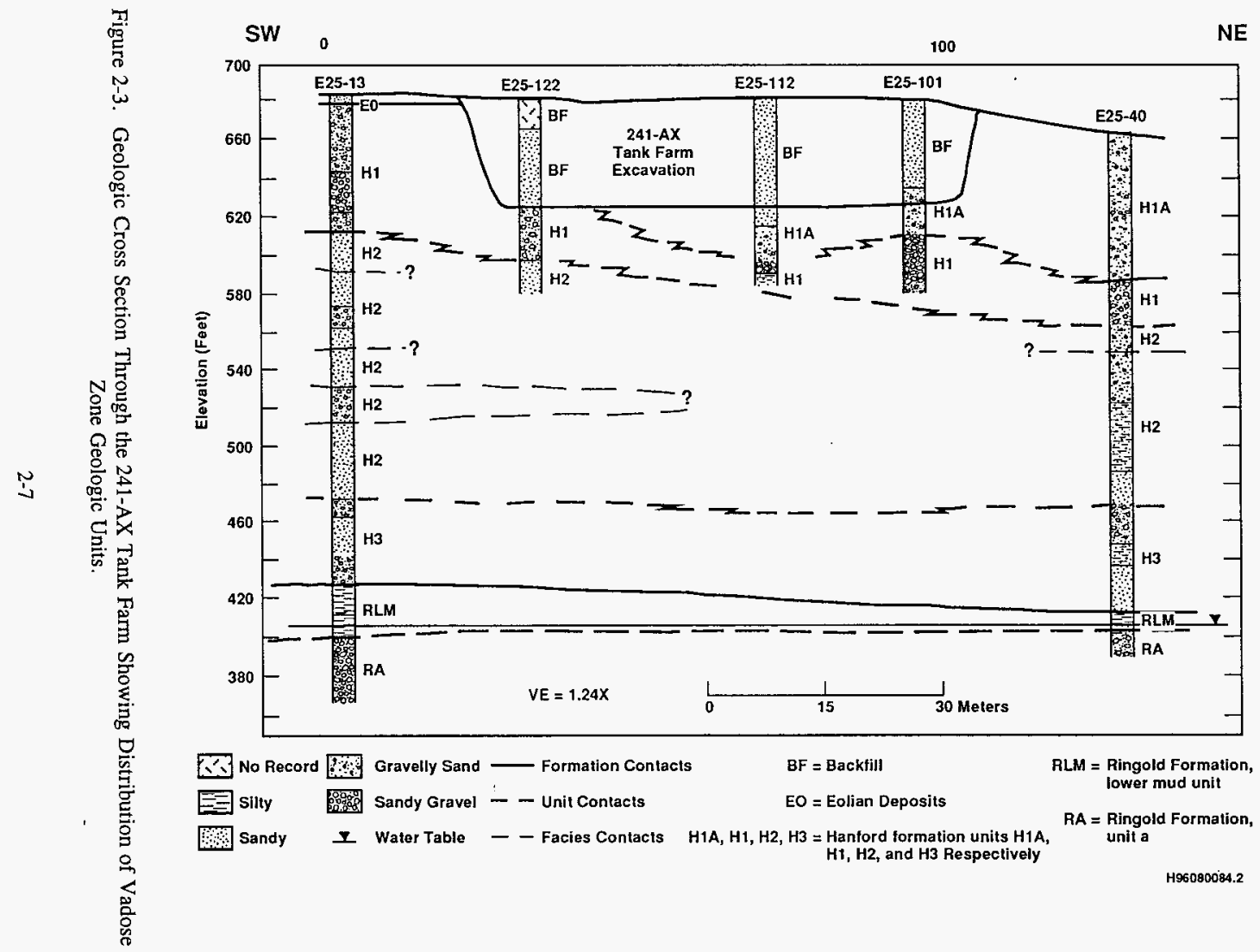




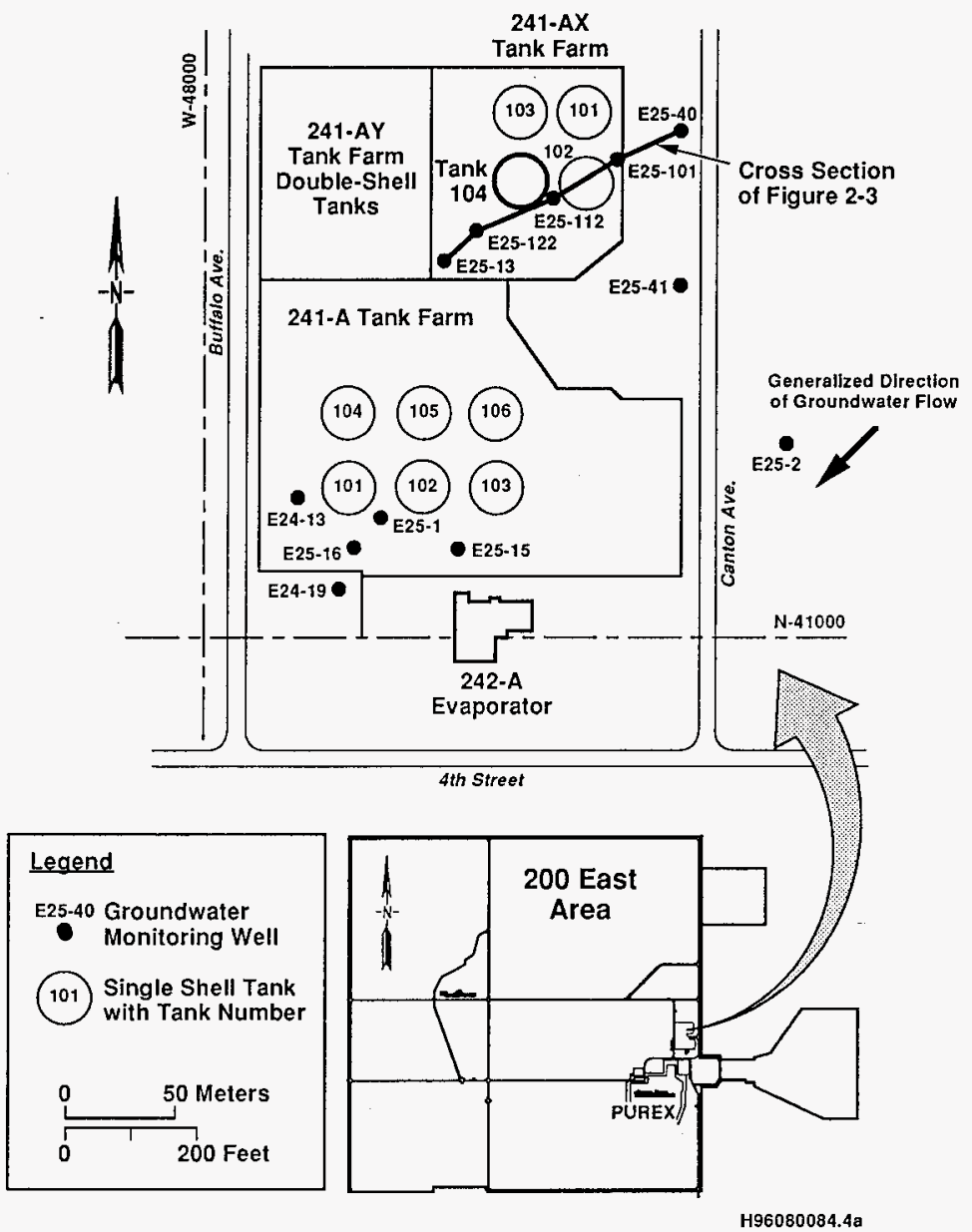

Figure 2-4. Wells and Cross Section Location Map. 
2.2.4.3 Hanford Unit H2. Unit $\mathrm{H} 2$ is 35 to $46 \mathrm{~m}$ (114 to $151 \mathrm{ft}$ ) of slightly-silty very coarse to medium sand, and very coarse to medium sand underlying unit H1 (Price and Fecht 1976) (Figures 2-2 and 2-3). Only the three groundwater wells (Section 2.2.4) fully penetrate unit H2, the thickest vadose zone stratigraphic unit near the 241-AX Tank Farm. Based on lithologic descriptions from these wells, examination of borehole geologic logs, and characteristics found in outcrops of analogous strata the lithologies comprising unit $\mathrm{H} 2$ are dominated by well-stratified sand typical of the sanddominated facies. Although not explicitly described in borehole logs at the 241-AX Tank Farm, the sandy strata forming unit $\mathrm{H} 2$ are inferred to contain thin $(<0.5 \mathrm{~m}[<1.6 \mathrm{ft}])$, lenticular silt interbeds. This interpretation is based on the presence of clay-rich ( $>20 \mathrm{wt} \%$ ) samples in the ROCSAN database, borehole geologic log descriptions from similar strata at other locations, and investigations at adjacent sites (Caggiano and Goodwin 1991) and outcrops of similar lithologies (Lindsey et al. 1992, 1994a,b). Borehole logs, coupled with grain size data in ROCSAN, also indicate the presence of gravelly sand intervals as much as $7 \mathrm{~m}(23 \mathrm{ft})$ thick. Several gravelly intervals may be laterally persistent beneath the entire site.

2.2.4.4 Hanford Unit H3. The lower part of the Hanford formation consists of an interstratified sequence of sand and gravel facies referred to as unit H3 (Figures 2-2 and 2-3). The three groundwater wells (Section 2.2.4) are the only borings at the 241-AX Tank Farm that penetrate unit $\mathrm{H} 3$. The limited information available from the three wells and analogous strata elsewhere, suggests unit $\mathrm{H} 3$ has bedding features and mud content similar to what is found in unit $\mathrm{H} 1$. However, the number, thickness, and lateral extent of individual gravel beds may be less in unit $\mathrm{H} 3$ than in unit $\mathrm{H} 1$. Unit $\mathrm{H} 3$ ranges from $\sim 10$ to $14 \mathrm{~m}(\sim 33$ to $46 \mathrm{~m})$ thick.

2.2.4.5 Ringold Formation. The Ringold Formation lower mud unit is the lowermost stratigraphic unit in the vadose zone beneath the 241-AX Tank Farm (Figures 2-2 and 2-3). The unit consists of silt- and clay-dominated lacustrine and overbank deposits of facies associations IV and III, respectively. At the site the lower mud unit ranges from $\sim 3$ to $8.5 \mathrm{~m}(\sim 10$ to $28 \mathrm{ft})$ thick, and dips northwest. The water table is -3 to $5 \mathrm{~m}(\sim 10$ to $16.4 \mathrm{ft})$ below the top of the unit. Because only three wells penetrate the unit, its continuity beneath the 241-AX Tank Farm is uncertain. Its absence in wells at other nearby facilities suggests that the lower mud unit may not completely underlie the site. If the lower mud unit is absent anywhere beneath the 241-AX Tank Farm, the water table will occur in Ringold unit A. Unit A consists of consolidated, variably cemented fluvial sand and gravel.

\subsection{HYDOLOGY}

Hanford Site hydrogeology is discussed in several reports (Gephart et al. 1979; Graham et al. 1981; Graham et al. 1984, Law et al. 1987; DOE 1988; and Delaney et al. 1991). This section summarizes the hydrology of the Hanford Site, 200 East Area, and the 241-AX Tank Farm.

\subsubsection{Saturated Zone}

The saturated zone in the Pasco Basin is characterized by a multi-aquifer system consisting of four hydrogeologic units corresponding to the upper three formations of the CRBG and the sediments overlying the basalts. Confined zones in the basalt aquifers are present in the sedimentary interbeds and/or interflow zones that occur between dense basalt flows. The main water-bearing portions of the interflow zones are networks of interconnecting vesicles and fractures of the flow tops and flow bottoms (DOE 1988). The aquifer above the basalt is regionally unconfined and is contained largely within the sediments of the Ringold Formation and Hanford formation. 
The uppermost aquifer system beneath the Hanford Site lies at depths ranging from $<0.3 \mathrm{~m}$ $(<1 \mathrm{ft})$ below ground surface near West Lake and the Columbia and Yakima Rivers to $>107 \mathrm{~m}$ $(>350 \mathrm{ft}$ ) in the central portion of the Cold Creek syncline. The position of the water table in the western portion of the Hanford Site is generally within Ringold unit $\mathrm{E}$ gravels. The water table in the eastern portion of the Hanford Site is generally within the Hanford formation. The bottom of the uppermost aquifer system is defined as the top of the uppermost basalt flow. However, fine-grained overbank and lacustrine deposits in the Ringold Formation locally form confining layers for Ringold fluvial gravels underlying gravel unit $\mathrm{E}$. The uppermost aquifer system is bounded laterally by anticlinal basalt ridges and is $\sim 152 \mathrm{~m}(\sim 500 \mathrm{ft})$ thick near the center of the Pasco Basin. Hydraulic conductivities for the Hanford formation (601 to $3,048 \mathrm{~m} /$ day [2,000 to $10,000 \mathrm{ft} /$ day]) are much greater than those of the gravel facies of the Ringold Formation (186 to $930 \mathrm{~m} /$ day $[610$ to $3,050 \mathrm{ft} /$ day]) (Graham et al. 1981).

At the 241-AX Tank Farm, groundwater occurs at an elevation of $\sim 122.5 \mathrm{~m}(401.8 \mathrm{ft})$ above mean sea level. Consequently, the water table lies within the Ringold lower mud unit. The dominant unit in the saturated zone is gravel and sand of the Ringold unit A.

Hydraulic gradient is extremely low in the vicinity of the 241-AX Tank Farm. Figure 2-5 illustrates the water table in the 200 East Area in June 1995. Due mostly to the decay of the B-Pond groundwater mound, the hydraulic gradient has continued to decline.

\subsubsection{Unsaturated Zone}

The dominant vadose zone geologic unit at the Hanford Site is the Hanford formation. Vadose zone physical conditions across the Hanford Site and 200 Areas show variations similar to those displayed by the uppermost aquifer system. Vadose zone sediments range from open framework gravel-dominated facies of the Hanford formation, to interbedded silt and sand of the silt-dominated facies, to calcium carbonate-rich deposits of the Plio-Pleistocene unit, to cemented gravel of the Ringold Formation. Available Van Genuchten curve fitting parameters for the major stratigraphic units beneath the 200 Areas are summarized in Connelly et al. (1992a,b) and Khaleel and Freeman (1995). Examining the data in these reports shows these curve fitting parameters are highly variable and that an accurate assessment of them is dependent on site-specific data.

The site-specific data needed to provide a basis for such assessments are not available for the 241-AX Tank Farm. Beneath the 241-AX Tank Farm, vadose zone lithologies are dominated by uncemented sand-dominated facies with minor, intercalated gravel- and silt-dominated facies.

\subsection{VADOSE ZONE AND GROUNDWATER CONTAMINATION}

For wells monitored in the 241-AX Tank Farm RCRA monitoring network critical mean calculations for field-specific conductance, $\mathrm{pH}$, and total organic halogen in groundwater show no exceedances. However, the site is located in or near tritium, arsenic, chromium, cyanide, ${ }^{99} \mathrm{Tc}$, and ${ }^{129}$ I plumes. Water levels in groundwater monitoring wells adjacent to the 241-AX Tank Farm also show a steady decrease in water levels over time. Since 1990 , water levels in the wells have dropped $\sim 1 \mathrm{~m}(\sim 3.3 \mathrm{ft})$. 


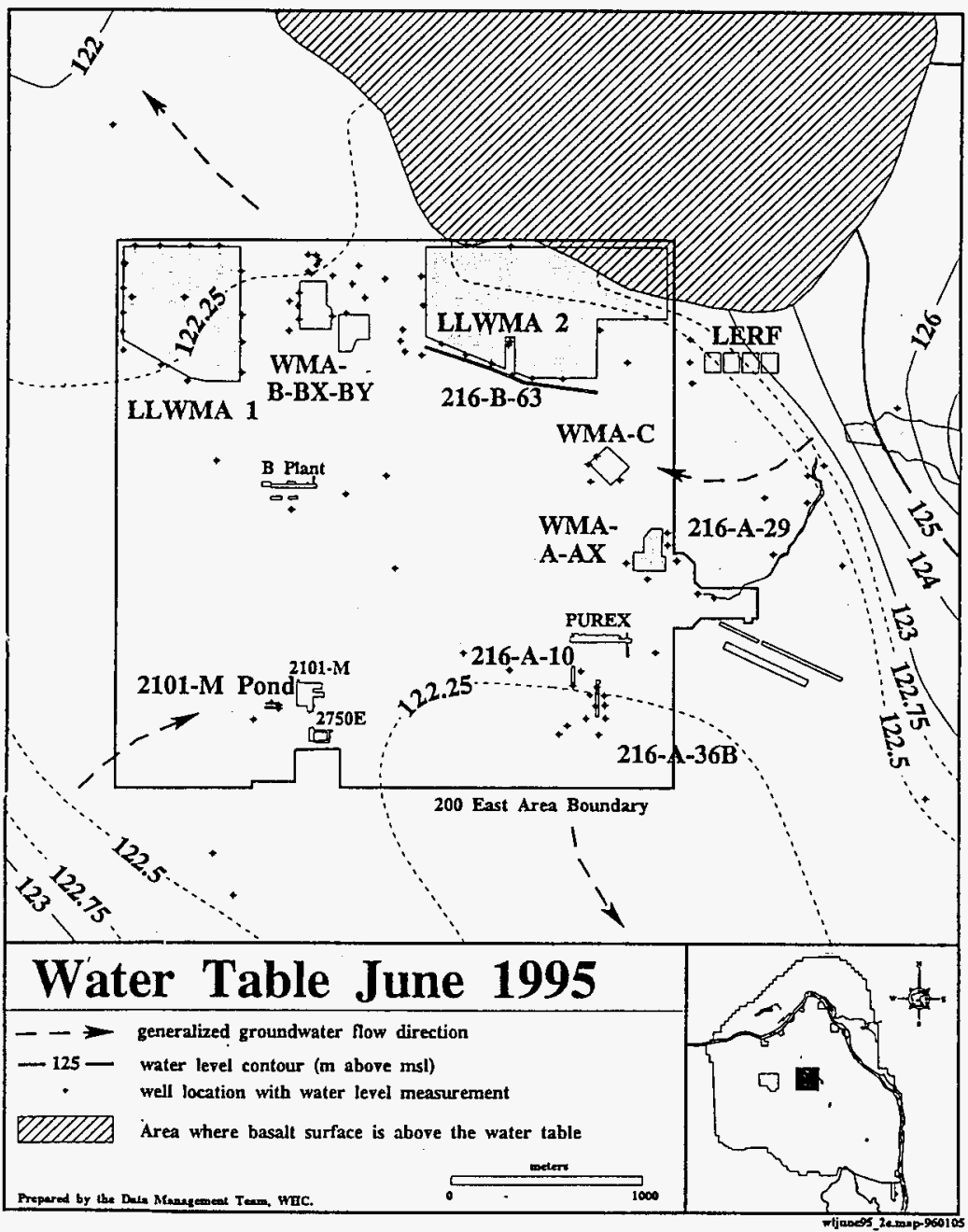

Figure 2-5. Water Table Map for the 200 East Area, June 1995. 
The 241-AX Tank Farm is located on the north edge of the tritium plume that extends to the southeast out of the 200 East Area. Tritium levels in the wells at the tank farm are $<20,000 \mathrm{pCi} / \mathrm{L}$; the drinking water standard for this constituent. Technetium-99 levels in groundwater wells up to $167 \mathrm{pCi} / \mathrm{L}$ have been reported in the immediate vicinity of the 241-AX Tank Farm (Ford 1993). The drinking water standard for ${ }^{99} \mathrm{Tc}$ is $900 \mathrm{pCi} / \mathrm{L}$. Iodine- 129 levels in the groundwater wells at the 241-AX Tank Farm range from 1 to $5 \mathrm{pCi} / \mathrm{L}$ (DOE-RL 1995). The drinking water standard for ${ }^{129} \mathrm{I}$ is $1 \mathrm{pCi} / \mathrm{L}$. Concentrations of arsenic and cyanide are below their respective drinking water standards (Ford 1993). Chromium has occurred intermittently in concentrations greater than drinking water standards (Caggiano 1996).

Evidence suggesting the presence of subsurface vadose zone radioactive contamination at the SST farms is found in tank farm surveillance reports (Welty 1988, Hanlon 1995) and tank-specific reports. Tank farm surveillance reports present hundreds of pages of subsurface radioactive contaminant data in tabular form for individual tank farm dry wells. Maps showing the distribution of this contamination generally are not included in these reports. These surveillance reports, coupled with the ongoing tank farm borehole spectral gamma logging program, suggests radioactive contamination is present locally in the vadose zone immediately underlying the tank farms. However, most of the data is based on gross gamma logs, and because spectral data are lacking, the vertical and lateral extent of such contamination at the tank farms is generally not known. This also is the case at the 241-AX Tank Farm, although the absence of contamination encountered during drilling of groundwater wells and subsequent water sampling suggests that radioactive contamination should not be widespread. 


\subsection{INFORMATION NEEDS}

\subsection{UNRESOLVED SINGLE-SHELL TANK CLOSURE ISSUES}

The Single-Shell Tank Closure Work Plan (SSTCWP) (DOE-RL 1996b) defines the pathway for attaining final closure of the Hanford Site SSTs by identifying unresolved issues affecting closure and the means to resolve those issues. The SSTCWP describes the regulatory processes, identifies unresolved issues and major decisions, and provides a means to track the status of each issue and decision.

The SSTCWP identifies 26 issues that must be resolved to close SSTs. Only one issue has been resolved thus far. Of the 25 remaining issues, 17 require resolution of Tank $241-\mathrm{AX}-104$ before a decision can be made to proceed with specific closure actions for that tank, without additional retrieval of waste. Twelve of the 17 issues require site-specific subsurface hydrologic characterization information for resolution. These 12 issues are:

- May SSTs, residual waste in SSTs, ancillary equipment, residual waste in ancillary equipment, and contaminated soils be classified as low-level waste (Issue 3.02)?

- How will residual tank waste and site conditions be characterized (Issue 4.01)?

- What is the level of confidence that subsurface data adequately represent actual hydrogeologic conditions that affect the transport of residual contaminants from Tank 241-AX-104 (Issue 4.02)?

- What will be the extent, concentration, and rate of movement of contamination from waste residues after completion of SST waste retrieval operations (Issue 4.03)?

- What sensitivity does the movement of residual contaminants have to various aspects of waste retrieval, natural recharge, and local hydrogeology (Issue 4.04)?

- What level of detail for borehole monitoring is needed for integration with waste retrieval and disposal (Issue 4.05)?

- What cost/benefit criteria should be applied to select the most appropriate waste retrieval technology (Issue 5.01)?

- How much waste associated with SSTs must be retrieved to comply with groundwater protection requirements and reduce long-term risk to the public to acceptable levels (Issue 5.02)?

- What data and information are required for credible performance and risk assessments (Issue 7.01)?

- What method will be used to quantify the allowable long-term, sitewide risk to the public from residual waste and onsite waste disposal, and how will the risk be apportioned to SST operable units (Issue 7.02)? 
- Until quantitative criteria for performance of closed SSTs are codified, what criteria should be used in the interim to select and optimize a preferred closure design from among alternatives (Issue 7.03)?

- In selecting a preferred approach for closing SSTs, what criteria will be used to balance increases in near-term occupational risk from waste retrieval and tank closure operations with decreases in long-term risk to the public (Issue 7.04)?

The resolution of these tank closure issues will begin by collecting key data that presently are not available. Data specific to the needs of the HTI will be collected by means of the technical approach described in Section 3.2.

\subsection{TECHNICAL APPROACH TO ISSUE RESOLUTION}

Each of the 12 unresolved issues listed in Section 3.1 can be related to one or both of two fundamental questions:

- What are the potential effects and risks associated with contaminated liquid leaking from the tank?

- What are the potential effects and risks associated with natural and artificial recharge permeating or leaching soils previously contaminated by tank leaks or operations?

Answering these two fundamental questions and, hence, resolving the issues listed in Section 3.1 hinges on a thorough understanding of the details of the hydrogeologic framework of the Tank 241-AX-104 site. Moreover, the consequences of tank closure activities or tank status will be understood in terms of specific and overall risks only if pathways inherent to the natural host material are identified and quantified. Activity (1) (Section 1.1) will provide data that contributes to answering the fundamental questions and thus contributes to resolution of the 18 unresolved issues. This section briefly describes the process for formulating tasks derived to resolve these problems.

Identifying and quantifying subsurface materials properties is accomplished by the appropriate physical and chemical testing of the materials. Testing is essential to determining the hydrogeologic framework, provides a basis for immediate decisions, if necessary, and forms the database for predictive modeling. Test selection is based on the goal of answering the two questions posed above. The appropriate testing activities are outlined in Section 1.3. Tasks required to implement testing activities are described in detail in Section 4.0.

This section describes the technical approach used to determine the scope of the hydrogeologic testing activities presented in this work plan. To ensure the objectives of the plan (Section 1.3) are met and the efficiency of data collection and analysis is maximized, a sequential process is necessary. This process will:

- Identify the scope of data needs

- Evaluate adequacy of existing data

- Identify additional data needs not met by existing data

- Select methods for additional data collection and analysis

- Ensure methods and additional data will fulfill needs (data quality objectives)

- Implement additional data collection and analysis. 
WHC-SD-WM-WP-337, Rev. 0

These elements, in terms of the present work plan, are explained in the following sections.

\subsubsection{Identifying Scope of Data Needs}

The information needed to secure a viable plan for SST closure is determined by the unresolved tank issues presented in Section 3.1. The precise type of information needed, in turn, dictates the subsurface investigation activities summarized in Sections 1.1 and 1.3, and discussed in detail in Section 4.0.

Physical properties data on the natural materials surrounding and underlying Tank 241-AX-104 is acquired by gleaning needed elements from existing information, or by drilling, sampling, and testing the site materials for the desired parameters.

\subsubsection{Evaluating Adequacy of Existing Data}

To avoid redundancy and unnecessary expenditures, background and historical information were assessed for applicable data. Of primary interest are the quality and availability of data sets for physical properties of soil adjacent to the 241-AX-104 Tank, and similar data sets for other areas of the Hanford Site that might serve as useful analogues for the 241-AX-104 Tank area. Information is also sought for groundwater and soil chemistry to complete the subsurface characterization at Tank 241-AX-104. Background information is summarized in Section 2.0 and specific topical areas lacking data are described here.

Review of the existing soil properties data for the 200 East Area indicates that these data are insufficient to provide the site-specific information required for numerical modeling (Section 1.3). Discrepancies in sample descriptions, differences in sample collection and analysis techniques, and incomplete sampling of the lithologic sections of interest prevent the direct correlation of existing data to the 241-AX-104 Tank site.

\subsubsection{Identifying Data Needs}

By identifying information deficiencies, a determination was made of specific needs for additional data collection and analysis. These specific additional needs are a product of comparing the sum of subsurface information needed to resolve tank closure issues (Section 3.2) with existing applicable information. The identification of additional data needs, in turn, dictates specific tasks for the work plan. The tasks are described in Section 4.0.

\subsubsection{Selecting Methods for Collecting Additional Data}

Based on the identification of additional data needs and hence, tasks to gather data, specific data-collection methods were selected. These methods, such as drilling, groundwater analyses, and soil testing, are selected from an array of accepted industry standards. The specific methods are described and/or cited in Section 4.0. 


\subsubsection{Ensuring Methods and Additional Data Fulfill Needs (Data Quality Objectives)}

The intent of data quality objectives (DQO) is to ensure that the type, quantity, and quality of data gathered is sufficient to address the fundamental questions of Section 3.2.1, and hence, the specific questions listed in Section 3.1. The U.S. Environmental Protection Agency (EPA) has formulated a seven-step DQO process whereby data needs are assessed and problem resolution is addressed. The seven steps are:

(1) State problem

(2) Identify decisions

(3) Identify data needed to make decisions

(4) Identify scope of data collection

(5) Define basis for making the decision

(6) Place limits on decision errors

(7) Optimize sampling design.

The DQO process is intended to be flexible, and to have both quantitative and qualitative aspects. This process seeks to ensure cost-effective, efficient planning that delimits field and laboratory activities to those necessary and sufficient to resolve the stated problem(s) and make the incumbent decisions. The process has been adapted to the subsurface characterization work plan presented here, and provides the basis for the technical approach.

To ensure that methods selected for gathering additional data are of sufficient quality to fulfill data needs, comparisons are applied beforehand between methods and expected results.

For example, the selected drilling technique will produce soil samples of a nominal size and quality that will allow application of the appropriate testing techniques to gather the required data. Similarly, groundwater sampling and analysis techniques provide data quality that is within predetermined quantitation limits. Departures from the methods, or the results from application of the method, are readily demonstrated, either quantitatively or qualitatively.

Section 4.0 describes the tasks and the corresponding methods that will provide the additional data needed. In conjunction with each method description are predictable outcomes that yield a nominal result. As an example, analytical procedures to determine soil and groundwater chemistry are defined by the specific methods that will produce results at or above predetermined detection limits and limits of quantitation. The completeness, accuracy, and precision of these values are also quantifiable and predictable within established limits; thus, the quality of the product is measurable.

\subsubsection{Implementing Data Collection and Analysis}

When the foregoing DQO process (Sections 3.2.1 through 3.2.5) has been satisfied, collection of additional data may begin. Collection and analysis of pertinent data for this work plan is described in Section 4.0. The anticipated schedule for implementation is presented in Section 6.0. 


\subsection{TASK DESCRIPTIONS}

This section describes the primary tasks and associated methods used for subsurface characterization. The tasks are derived from specific technical needs described in Section 3.0. The methods described below are those developed by, and/or adopted by the Westinghouse Hanford Company (WHC) Geosciences Group (Geosciences) for RCRA site investigation and monitoring. Standards, procedures, and instructions for implementing methods are cited for each activity. As of October 1, 1996, WHC and ICF Kaiser Hanford (ICF KH) responsibilities will be assumed by the Fluor Daniel Hanford team of contractors. All standards, procedures, and instructions as detailed below will remain intact.

\subsection{BOREHOLE DRILLING AND WELL CONSTRUCTION}

The approach to resolving technical issues requires that this task provides a representative location and structure (a borehole) for collection of sediment samples for physical and chemical analyses. The completed well will provide the sampling environment for groundwater quality background information. Rationale for selection of the borehole location, and specifications for drilling, construction, and development are described or referenced in this section.

\subsubsection{Location of Borehole}

The preferred location and two alternative locations for the borehole are shown in Figure 4-1. If conditions in the subsurface (e.g., due to obstructions, pipes, conduits, etc.) prove unfavorable for drilling at the preferred location, one of the alternative locations may be substituted. All three locations were chosen so as to locate the borehole as near as technically feasible to the 241-AX-104 Tank, yet outside of controlled zones that would impact safety margins. The preferred well site (approximate Hanford Coordinates: N41,890/W47,760) is located in an area northwest of the 241-AX-104 Tank that would best augment current coverage of subsurface information, enhance stratigraphic correlation with other nearby wells, and be least redundant of existing information.

\subsubsection{Borehole Drilling}

Site preparation and investigation will be conducted before drilling is permitted to begin. Pre-drilling preparations and documentation include: Hazardous Waste Operations Permit (HWOP) (if required), excavation permit, site surveys, Ecology "start card," National Environmental Policy Act (NEPA) checklist, Job Safety Assessment, and purgewater determination and waste management plan(s). These preparations are made by ICF KH and/or WHC projects, and will be completed before the drill is mobilized to the site.

Prior to the beginning of drilling and immediately following completion of well construction, the drill and related equipment will be decontaminated and cleaned, as appropriate, in accordance with environmental investigations instructions (EII) 5.4 "Field Cleaning and/or Decontamination of Equipment" (WHC 1988) and WAC 173-160-530 Minimum Standards for Construction and Maintenance of Wells (Ecology 1994). 
WHC-SD-WM-WP-337, Rev. 0
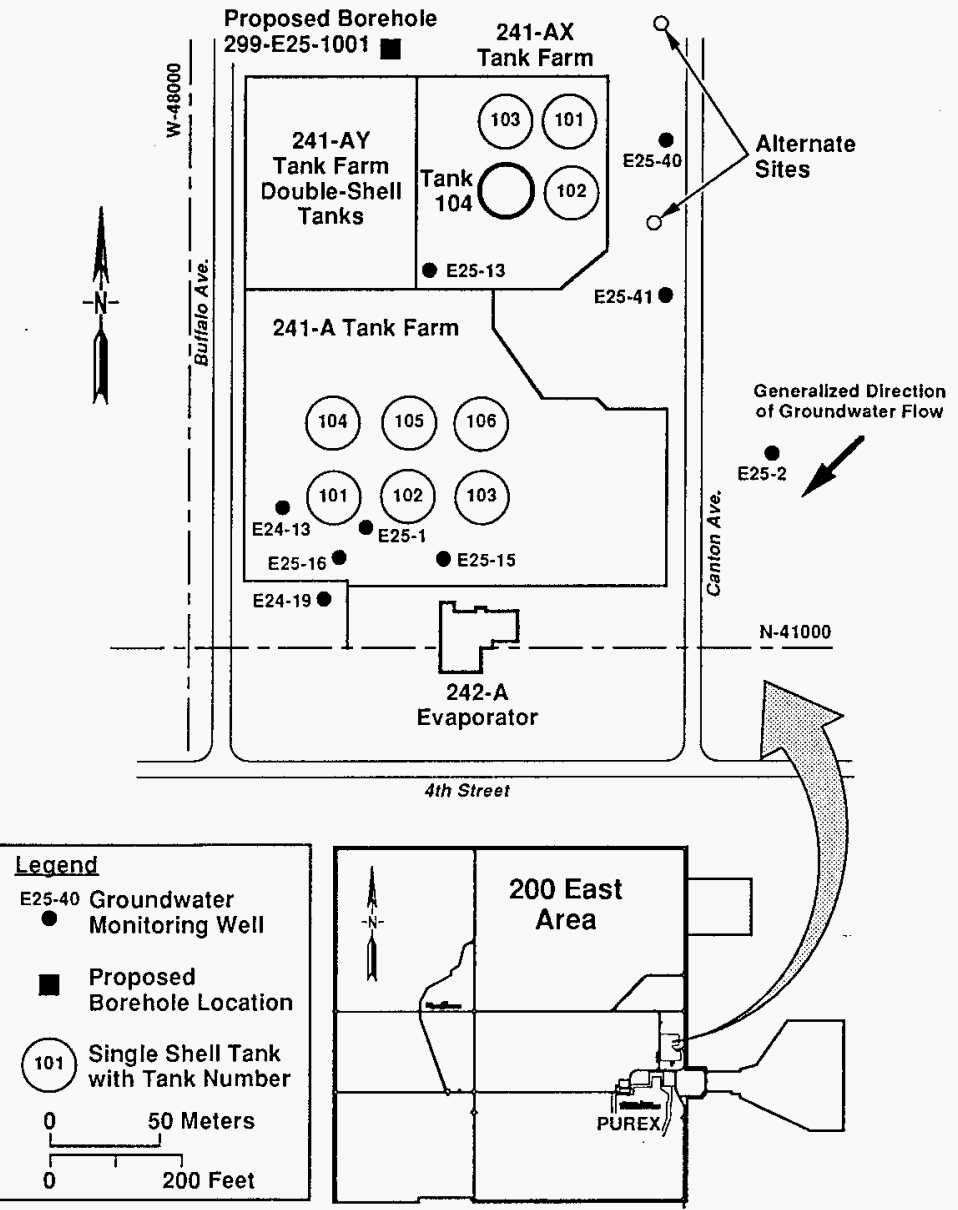

H96080084.4

Figure 4-1. Primary and Alternate Borehole Locations. 
The upper $\sim 5 \mathrm{~m}(\sim 15 \mathrm{ft})$ of the borehole may be hand dug or vacuum excavated to ensure avoidance of undetected infrastructures. Below $\sim 5 \mathrm{~m}(\sim 15 \mathrm{ft})$ depth the borehole will be drilled by cable-tool method. Drilling of the borehole will conform to Generic Well Specification (Reynolds 1996) and WAC 173-160 (Ecology 1994). Drilling is expected to require $\sim 30$ days to complete (see schedule in Section 6.0), including time required to conduct initial geophysical surveys (see Section 4.6).

Based on an estimated surface elevation of $202 \mathrm{~m}(662 \mathrm{ft})$ above mean sea level, the expected thickness of the vadose zone at the proposed borehole location is $\sim 79 \mathrm{~m}(\sim 260 \mathrm{ft})$. Total depth of the borehole is expected to be $\sim 87 \mathrm{~m}(\sim 285 \mathrm{ft}) \pm 6 \mathrm{~m}( \pm 20 \mathrm{ft})$ (Figure 4-2). Downsizing of temporary steel casing, from $0.25 \mathrm{~m}$ (10 in.) to $0.20 \mathrm{~m}$ (8 in.) diameter, will occur at a depth of $\sim 43 \mathrm{~m}(\sim 140 \mathrm{ft})$, or as directed by the wellsite geologist. Construction of a RCRA-standard Resource Protection Well (Ecology 1994) will commence following drilling, as described in Section 4.1.3.

\subsubsection{Well Construction and Development}

Upon completion of drilling, a RCRA-standard Resource Protection Well will be built according to WAC 173-160 (Ecology 1994) and Reynolds (1996). These specifications will ensure construction that accommodates RCRA-quality groundwater sampling and analysis as described in Section 4.6. The right side of Figure 4-2 illustrates a schematic representation of the anticipated well design.

The completed well will consist of a 4-in.-diameter stainless-steel casing and a $0.1-\mathrm{m} \times 6-\mathrm{m}$ (4-in. $x$ 20-ft) continuous wire wrap well screen (Figure 4-2). The well screen will be emplaced so

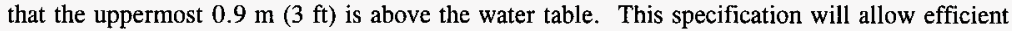
groundwater sampling, hydraulic testing, and operation of the groundwater flowmeter (Section 4.5).

Well development will be in accordance with Reynolds (1996) and EII 10.4 "Well Development Activities" (WHC 1988). The completed well will be pumped or bailed until a turbidity of $\leq 5 \mathrm{NTU}$ has been achieved in the discharge water, or sediment content is $<8 \mathrm{mg} / \mathrm{L}$. Well development will be completed prior to the flowmeter survey and hydraulic testing (Section 4.5) and groundwater sampling (Section 4.6).

\subsubsection{Pump Installation}

Normally, installation and testing of the dedicated sampling pump would immediately follow development. In the current plan, this procedure will be delayed until groundwater flowmeter surveys and dynamic hydraulic tests are completed, as described in Section 4.5. Following the flowmeter survey and hydraulic tests, a dedicated sampling pump will be installed per EII 6.4 (WHC 1988). The first groundwater purging and sampling event (Section 4.6) (except perched groundwater) will take place after flowmeter surveys, dynamic hydraulic test, and installation and testing of the dedicated sampling pump. 
This is a lithologic representation of proposed Well 299-E25-1001. Actual conditions and lithologies encountered in the new well may differ somewhat from this representation, unit contacts may vary by $\pm 15 \mathrm{ft}$.

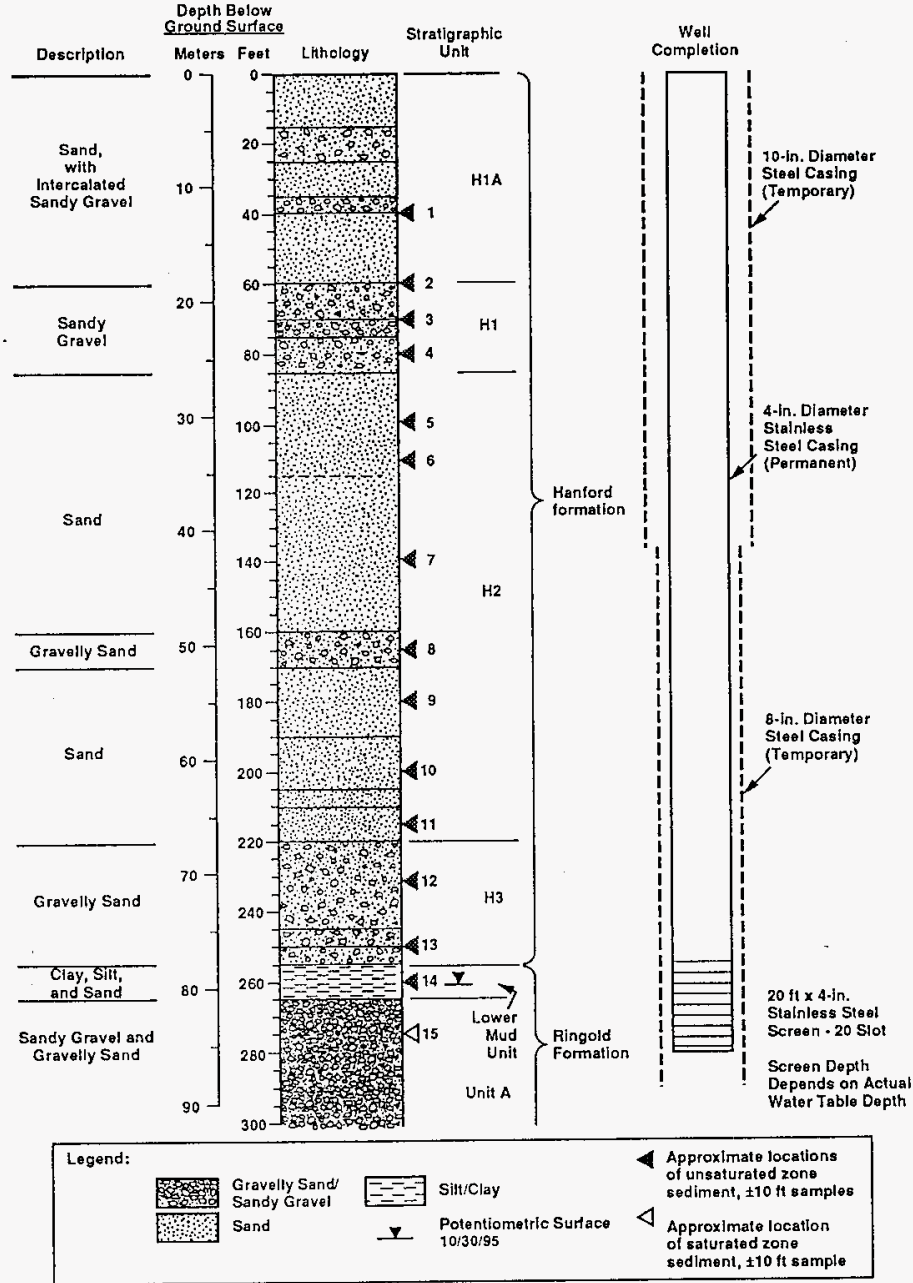

H96010183.3a

Figure 4-2. Well Construction Diagram and Lithologic Sample Locations. 
WHC-SD-WM-WP-337, Rev. 0

\subsection{LITHOLOGIC LOGGING}

Lithologic logging of cuttings, drive barrel samples, and split-spoon samples will be undertaken throughout drilling to identify lithologic and stratigraphic features as they are encountered. In addition, lithologic grab samples from cuttings will be collected and described every $1.5 \mathrm{~m} \mathrm{(5 \textrm {ft } )}$ and at changes in lithology throughout the drilling process. Geologic logging and sample collection will be done by the wellsite geologist in accordance with Reynolds (1996), EII 9.1 "Geologic Logging" (WHC 1988), and Instructions for Borehole Sampling (Reynolds and Lindsey 1994).

\subsection{BOREHOLE SEDIMENT SAMPLING AND ANALYSIS}

Sediment samples will be collected within 15 intervals in the borehole during drilling procedures; 14 samples in the vadose zone and one in the saturated zone (Figure 4-2). Samples for physical tests, column leach tests, and volatile organic aerosol (VOA) analyses (Sections 4.3.2.1 through 4.3.2.3) will be collected in split-spoon tube. Samples for all soils chemistry analyses, except VOA, will be collected in the drive barrel of the drill within the same intervals. Details of sample locations, targeted lithologies, and analytical methods for soils analyses are described in the following sections.

\subsubsection{Sampling Intervals}

Borehole sediment sampling described in this work plan is designed to acquire samples from each of the major lithologies and stratigraphic units underlying the site. The expected geology at the 241-AX Tank Farm, interpreted from tank farm vadose borings and groundwater wells 299-E25-13, $-40,-41$, and 299-E27-2, is described in Section 2.2.4 and illustrated on Figures 2-2, 2-3, and 4-2. Because none of the deep groundwater borings associated with the 241-AX Tank Farm are within the 241-AX Tank Farm boundary, depths to sample points and target lithologies (Figure 4-2) are approximations. Actual sampling depths are expected to vary by $\pm 3 \mathrm{~m}$ ( $\pm 10 \mathrm{ft})$ from the planned depths.

The following discussion lists the samples, the stratigraphic units the samples are in, and the types of lithologies to be sampled. For each of the sampling events, sampling will focus on collecting material representative of dominant lithologies. Sampling of important subordinate lithologies also will occur as detailed below. The anticipated sample locations are shown in Figure 4-2.

Sample $1(12 \mathrm{~m}[40 \mathrm{ft}])$. Hanford formation unit H1A, sand with intercalated gravel. This interval is representative of material removed from the site of 241-AX Tank Farm during excavation and construction, providing the backfill material used in the 241-AX Tank Farm.

Samples $2(18.3 \mathrm{~m}[60 \mathrm{ft}]) .3(21.3 \mathrm{~m}[70 \mathrm{ft}])$, and $4(24.4 \mathrm{~m}[80 \mathrm{ft}])$. Interbedded sand and gravel at and below interface between Hanford formation units H1A and H1. Samples will be representative of strata immediately below the base of the 241-AX Tank Farm.

Samples $5(30.5 \mathrm{~m}[100 \mathrm{ft}]), 6(34 \mathrm{~m}[110 \mathrm{ft}]), 7(43 \mathrm{~m}[140 \mathrm{ft}]), 8(50 \mathrm{~m}[165 \mathrm{ft})), 9(55 \mathrm{~m}$

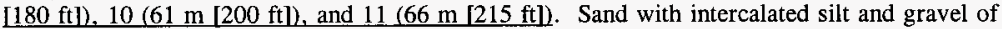
Hanford formation unit H2. This is the dominant vadose zone unit at the 241-AX Tank Farm. However, it is under sampled because of the small numbers of borings at and adjacent to the 241-AX Tank Farm that penetrate it. If a silty horizon is encountered near one of the planned sample 
depths, it will be sampled. Samples 7, 8, and 9 may encounter significant gravel, and if encountered, the gravel should be sampled.

Samples $12(70 \mathrm{~m}[230 \mathrm{ft}])$ and $13(76 \mathrm{~m}[250 \mathrm{ftl})$. Interbedded gravel and sand of Hanford formation unit H3. Samples from this unit, near the base of the vadose zone, are rare throughout the 200 East Area.

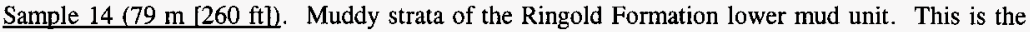
lowermost unit in the vadose zone beneath the 241-AX Tank Farm and is also the finest-grained unit. It has not been analyzed in samples from the vicinity of the 241-AX Tank Farm to determine its influence on flow and transport pathways.

Sample $15(84 \mathrm{~m}[275 \mathrm{ft}])$. Sandy gravel of Ringold Formation unit A. This is the dominant saturated zone unit beneath the 241-AX Tank Farm.

\subsubsection{Sediment Analysis}

Sediment physical properties and baseline chemistry will be determined for samples collected during the drilling of well 299-E25-1001. Column leach tests will also be conducted on sediment samples and the leachate will be analyzed for potential contaminants. The objectives of these tests are to (1) obtain flow and transport information through the use of physical properties analyses, (2) determine background sediment chemistry in vicinity of the 241-AX Tank Farm, and (3) estimate the degree to which contaminants may be mobilized in the vadose zone by leaching.

All analyses of sediment samples will be in accordance with the procedures and instructions provided in Stauffer and Washington (1995), WHC (1988), and WHC (1992a). The determination of sediment chemistry and the analysis of leachate samples will be performed in accordance with Horton (1996).

4.3.2.1 Determination of Sediment Physical Properties. Sediment samples will be analyzed for the physical properties listed in Table 4-1. These parameters will be determined to provide data for numerical simulations of contaminant flow and transport in the vadose zone. Methods for physical properties analyses are listed in Table 4-1. These methods are standard for the American Society of Testing and Materials (ASTM) (ASTM 1992) and the American Society of Agronomy (ASA) (Klute 1986). Appropriate in-house laboratory procedures may also be used upon approval from the technical lead. 
Table 4-1. Sediment Physical Properties and Test Methods.

\begin{tabular}{|l|l|}
\hline \multicolumn{1}{|c|}{ Physical Property } & \multicolumn{1}{c|}{ Method } \\
\hline Bulk Density & ASA Chapter 13, Section 13-2 \\
\hline Calcium Carbonate & ASTM D 4373 \\
\hline Grain Size Distribution & ASTM D 422 \\
\hline Moisture Content & ASTM D 2216 \\
\hline Moisture Retention & In-house laboratory procedure \\
\hline Specific Gravity & ASTM D 854-83 and ASTM C 127-84 \\
\hline Total Porosity & ASA Chapter 18, Section 18-2 \\
\hline Unsaturated Hydraulic Conductivity & ASTM D 18.21 (Subcommittee number) \\
\hline
\end{tabular}

4.3.2.2 Determination of Baseline Sediment Chemistry. Constituents selected for sediment chemistry analyses and corresponding methods are listed in Table 4-2. The constituents were selected from 40 CFR 265 Subpart F, Appendix IX, Groundwater Analytes (40 CFR) and the site-specific analytes sampled in groundwater for the SST WMA A-AX (Caggiano and Goodwin 1991). The methods listed are from Test Methods for Evaluating Solid Wastes (EPA 1986), Methods for Chemical Analysis of Water and Wastes (EPA 1979), and the Annual Book of ASTM Standards (ASTM 1992). Other EPA or ASTM methods may be substituted for those specified if the laboratory selected to conduct the analyses can demonstrate that the alternative methods are comparable. For some methods, in-house laboratory procedures may be acceptable.

Sediment samples analyzed for metals by SW-846 6010A, 7421, 7060, 7740, or 7841 will be digested according to SW-846 3050. Samples analyzed for organic constituents will be prepared by SW-846 3510B (Separatory Funnel Liquid-Liquid Extraction), 3550A (Ultrasonic Extraction extraction of nonvolatiles and semivolatiles), and 5030A (Purge-and-Trap - extraction of volatile organics), unless an alternative preparatory procedure is contained within the methods specified in Table 4-2. The preparatory methods for the radiological analyses will be in accordance with the in-house procedures of the selected laboratory.

4.3.2.3 Column Leach Tests. Column leach tests will be conducted in accordance with WHC (1992b) unless the technical lead designates a comparable method. Samples from four of the intervals described in Section 4.3.1 will be selected for the column leach tests. Leachate collected during the column leach tests will be analyzed for anions, inductively coupled plasma (ICP) metals, and $\mathrm{pH}$. These analyses will provide information about the potential mobility of inorganic analytes. Table 4-3 lists the methods that will be used for these analyses. 
WHC-SD-WM-WP-337, Rev. 0

Table 4-2. Sediment Chemistry and Test Methods.

\begin{tabular}{|c|c|}
\hline Constituent & Method \\
\hline Anions & ASTM D4327 or EPA 300.0 \\
\hline Arsenic & SW-846 7060 or $6010 \mathrm{~A}$ \\
\hline Chlorinated Herbicides & SW-846 8150 \\
\hline Cyanide & SW-846 9012 \\
\hline Dibenzofurans & SW-846 8280 \\
\hline Dioxins & SW-846 8280 \\
\hline Gamma Spectroscopy & In-house laboratory procedure \\
\hline Gross Alpha & SW-8469310 \\
\hline Gross Beta & SW-846 9310 \\
\hline ICP Metals & SW-846 6010A \\
\hline Iodine-129 & In-house laboratory procedure \\
\hline Lead & SW-846 7421 or $6010 \mathrm{~A}$ \\
\hline Mercury & SW-846 7471 \\
\hline Organic Phosphate Pesticides & SW-846 8140A \\
\hline Pesticides & SW-846 8080 \\
\hline $\mathrm{pH}$ & EPA 150.1 or ASTM D-1293 \\
\hline Phenols & SW- $8468040 \mathrm{~A}$ or 8270 \\
\hline Polychlorinated Biphenyls & SW-846 8080 \\
\hline Selenium & SW-846 7740 or $6010 \mathrm{~A}$ \\
\hline Semivolatile Organic Compounds & SW-846 8270 (Appendix IX list) \\
\hline Strontium-90 & In-house laboratory procedure \\
\hline Sulfide & SW-846 9030 \\
\hline Technetium-99 & In-house laboratory procedure \\
\hline Thallium & SW-846 7841 or $6010 \mathrm{~A}$ \\
\hline Tritium & In-house laboratory procedure \\
\hline Total Plutonium & In-house laboratory procedure \\
\hline Total Uranium & In-house laboratory procedure \\
\hline Volatile Organic Compounds & SW-846 8260 (Appendix IX list) \\
\hline
\end{tabular}


WHC-SD-WM-WP-337, Rev. 0

Table 4-3. Sediment Leachate Analyses and Test Methods.

\begin{tabular}{|l|l|}
\hline \multicolumn{1}{|c|}{ Constituent } & \multicolumn{1}{|c|}{ Method } \\
\hline Anions & ASTM D4327 or EPA 300.0 \\
\hline ICP Metals & SW-846 6010 \\
\hline $\mathrm{pH}$ & EPA 150.1 or ASTM D-1293 \\
\hline
\end{tabular}

Alternative methods may be chosen upon approval from the technical lead.

\subsection{GEOPHYSICAL LOGGING}

Geophysical logging provides a means of verification of lithologic logging for stratigraphic interpretation, density (porosity) estimation, and relative moisture content of the sediments drilled. Geophysical methods will be used to help define hydrostratigraphic units to correlate these units among adjacent boreholes, and to identify zones that are potentially contaminated by gamma-emitting radionuclides. The borehole will be logged during drilling, following the placement of each string of temporary casing, and after well completion in accordance with WHC (1988), EII 11.1 "Geophysical Logging." Geophysical logging probes that may be used include high-resolution spectral gamma, neutron probe, and gross gamma. Only proven techniques with procedures adequate to control the quality of the data will be used. After completion, the well will be re-logged to provide a baseline for future radionuclide monitoring and tracking.

Optimal conditions for logging require that no more than one thickness of casing be present. Hence, logging will be done in stages before each additional casing is telescoped into place. The interval of the borehole containing the starter (surface) casing is exempt from this requirement unless the wellsite geologist requests that it be logged.

\subsection{DYNAMIC HYDRAULIC TESTING AND FLOWMETER SURVEY}

The purpose of aquifer testing is to determine aquifer hydraulic properties that, in turn, will help determine groundwater flow velocity (i.e., flow rate and flow direction). The results can be compared with hydraulic parameters determined from physical parameters testing of sediment samples. Aquifer testing in the new well will be limited to slug testing and flowmeter surveying. The slug test and flowmeter procedures are documented in EII 10.1 "Aquifer Testing" (WHC 1988). An aquifer test plan, containing specific guidance for both tests, will be designed prior to the beginning of testing.

Pumping tests will not be conducted. Results of a pumping test in a well of low discharge capabilities will only relate to the well's ability to produce water rather than the aquifer's ability to produce water. Slug tests and flowmeter analysis are low-cost techniques that have no wastewater disposal problems, but may still provide data on aquifer properties. A slug test is more likely to provide results representative of the aquifer when the aquifer response to a change in water level is slow (assuming the slowness is due to lower hydraulic conductivity of the aquifer and not a plugged or restrictive well screen), because the error related to well effects becomes more significant with greater speed of water level recovery. Flowmeter analysis, on the other hand, directly measures 
groundwater velocity (i.e., flow direction, as well as flow rate). The flowmeter is capable of measuring average flow rate as low as $0.04 \mathrm{ft} / \mathrm{d}(0.012 \mathrm{~m} / \mathrm{d})$ in any horizontal direction.

In addition to flowmeter testing in the new well, water levels will be measured semiannually in the well, and before each groundwater sampling event (see Section 4.6). These measurements will be compared with those in other nearby wells, then the larger data set will be used to construct water table maps and estimate the direction of groundwater flow and the horizontal hydraulic gradient. If water table maps and/or hydrographs indicate the direction of groundwater flow may be changing, the flowmeter will be used again.

\subsection{GROUNDWATER SAMPLING AND ANALYSIS}

This section describes the groundwater sampling and analysis plan for the completed well, and sampling of any perched groundwater zones encountered during drilling of the well. This activity ensures an adequate background evaluation of groundwater in the aquifer beneath the 241-AX-104 Tank, and augments information collected from RCRA interim-status groundwater monitoring for the 241-A and 241-AX Tank Farms (Caggiano 1996). Analysis for a comprehensive list of constituents screens the groundwater for potential contaminants and allows derivation of a condensed list of analytes. The condensed list may be used to establish a statistically defensible background profile of groundwater quality.

All sampling and analyses performed under this work plan are subject to the procedures and instructions provided in Stauffer and Washington (1995), WHC (1988), and WHC (1992a).

Additionally, groundwater sample analyses will be performed as defined by Horton (1996).

\subsubsection{Well Purging}

Prior to each sampling event, water level in the well will be measured according to EII 10.2 "Measurement of Groundwater Levels" (WHC 1988) and the well will be purged according to EII 5.8 "Groundwater Sampling" (WHC 1988). Nominally, the well will be purged until three well volumes have been removed. Alternatively, if the project scientist determines that drawdown of the water level in the well is excessive or recovery of the water level is unacceptably slow, the well may be purged until the field parameters of specific conductance, $\mathrm{pH}$, and temperature have stabilized. Purgewater generated will be handled according to EII 10.3 "Purgewater Management" (WHC 1988). Purging requirements may be applied to samples taken from perched groundwater horizons encountered during drilling, depending on the quantity of groundwater present and the drilling conditions.

\subsubsection{Groundwater Sampling}

Scheduled sampling of groundwater will occur following well construction and after all in-well testing is complete (Sections 4.4 and 4.5). Four quarters (1 year) of sampling will be performed, beginning with the first sample following well completion and testing. Additional samples may be collected from perched groundwater horizons, if encountered during drilling.

The collection, chain-of-custody protocol, transport of groundwater samples, and related field activities are governed by WHC (1994), WHC (1992a), and WHC (1988). 
A sampling event will be initialized at the request of the Geosciences technical lead. Geosciences will specify the constituents or analyte list (Section 4.6.4) and any preferred methods or special instructions. Sample Data and Laboratory Administration (SDLA) will receive the request and return a Sample Authorization Form (SAF) to Geosciences. The SAF will designate the analytical laboratory, analyses requested, analytical methods, bottle requirements, and holding times. From the completed SAF, Geosciences will generate the Groundwater Sample Field Record (GSFR) and chain of custody, and assign sample numbers from the Hanford Environmental Information System for data entry and storage. Through the GSFR, Geosciences will designate purgewater requirements, health physics requirements, bottle preparation requirements, field equipment, and specific radiation safety measures for sample handling.

\subsubsection{Groundwater Analysis}

Laboratory analytical requirements and methods will be stipulated by the SAF (Section 4.6.2). Analytical methods for selected constituents or constituent groups will be governed by SW-846 (EPA 1990). Data quality assurance procedures for groundwater and soil analytical data are specified in Stauffer and Washington (1995) and WHC (1988). Statistical analyses of groundwater chemistry results, if required, will be at the direction of the technical lead, and will follow procedures outlined by EPA $(1989,1992)$.

\subsubsection{Constituent List and Groundwater Sampling Schedule}

Constituents selected for analytical definition were selected based on the Appendix IX comprehensive analyte list (EPA 1986) and supplemental site-specific constituents derived from knowledge of Tank 241-AX-104 operation, and RCRA groundwater monitoring at the A-AX WMA (Caggiano 1996). Table 4-3 is the Appendix IX list and Table 4-4 lists supplemental site-specific constituents.

Following well development and hydraulic testing (see Sections 4.1 and 4.5), the initial sampling event will be implemented using both constituent lists (Table 4-3 and 4-4). After receipt and interpretation of results from the initial sampling event, the constituent list will be reduced to groundwater contamination-indicator parameters (Table 4-4), site-specific parameters (Table 4-4), and any constituents showing results of unexpected concentration from the initial sampling.

The constituent list may be further modified at the request of the technical lead, following the initial sampling event. Samples collected during drilling from perched groundwater zones will be analyzed for all constituents in Tables 4-3 and 4-4, unless otherwise determined by the technical lead.

Three subsequent sets of samples will be collected at 3-month intervals from the date of the first sampling event, until 1 full year (4 quarters) of sampling has been completed. 
Table 4-3. Appendix IX Analytical Methods and Constituent List for Groundwater Analyses. (sheet 1 of 4)

\begin{tabular}{|c|c|c|}
\hline AHALYTICAL KETHOOS & CONSTITUENIS OF CONCERN & POL PpD \\
\hline $\begin{array}{l}\text { ICP METALS } \\
\text { SW- } 8466010\end{array}$ & $\begin{array}{l}\text { AKIIMOHY } \\
\text { BARIUH } \\
\text { GERYLLLUH } \\
\text { CADHIUH } \\
\text { CHROHIUM } \\
\text { COBALY } \\
\text { COPPER } \\
\text { HICKEL } \\
\text { SILVER } \\
\text { TIN } \\
\text { VAHAOIUH } \\
\text { ZIHC } \\
\end{array}$ & $\begin{array}{l}300 \\
20 \\
3 \\
40 \\
70 \\
70 \\
60 \\
50 \\
70 \\
8000 \\
80 \\
20 \\
\end{array}$ \\
\hline $\begin{array}{l}\text { M METALS } \\
\text { SW-846 } 7060 \\
\text { SH-846 } 7421 \\
\text { SH-846 } 7470 \\
\text { SH-846 } 7740 \\
\text { SH-846 } 7841\end{array}$ & $\begin{array}{l}\text { ARSENIC } \\
\text { LEAD } \\
\text { MERCURY } \\
\text { SELEHIUM } \\
\text { THALLIUM }\end{array}$ & $\begin{array}{l}10 \\
10 \\
2 \\
20 \\
10\end{array}$ \\
\hline $\begin{array}{l}\text { CYAHIDE SW-846 } 9010 \\
\text { SULFIDE SW-846 } 9030\end{array}$ & $\begin{array}{l}\text { CYANIDE } \\
\text { SULFIDE }\end{array}$ & $\begin{array}{l}40 \\
10000\end{array}$ \\
\hline $\begin{array}{l}\text { PESTICIOES AND PCBS } \\
\$ H-846 \text { BOBO }\end{array}$ & 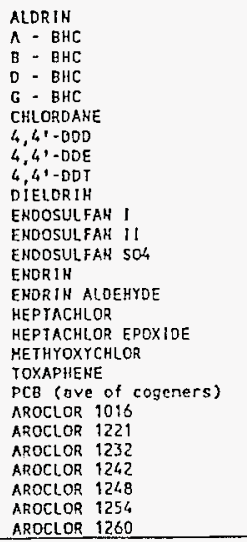 & $\begin{array}{l}0.05 \\
0.05 \\
0.05 \\
0.1 \\
0.05 \\
0.1 \\
0.1 \\
0.05 \\
0.1 \\
0.05 \\
0.1 \\
0.05 \\
0.5 \\
0.1 \\
0.2 \\
0.05 \\
1 \\
2 \\
2 \\
50\end{array}$ \\
\hline $\begin{array}{l}\text { CHLORIHATED HEREICIDES } \\
\text { SH-846 } 8150\end{array}$ & $\begin{array}{l}2,4-D \\
\text { DINOSEB; DHEP } \\
\text { SILVEX; } 2,4,5-T P \\
2,4,5-1\end{array}$ & $\begin{array}{l}10 \\
1 \\
2 \\
2 \\
\end{array}$ \\
\hline $\begin{array}{l}\text { ORGAHOPHOSFHORUS PESTICIOES } \\
\text { SH-846 } 8940\end{array}$ & $\begin{array}{l}\text { DISULFOTOH } \\
\text { HETHYL PARAIHIOH } \\
\text { PHORAJE }\end{array}$ & $\begin{array}{l}2 \\
0.5 \\
2\end{array}$ \\
\hline
\end{tabular}


WHC-SD-WM-WP-337, Rev. 0

Table 4-3. Appendix IX Analytical Methods and Constituent List for Groundwater Analyses. (sheet 2 of 4)

\begin{tabular}{|c|c|c|}
\hline AHALYTICAL METHOOS & COHSTITUENYS OF CONCERH & Pol ppb \\
\hline $\begin{array}{l}\text { VOLAT:LE ORGAHICS FOR GC/KS } \\
\text { SW- } 8468240\end{array}$ & 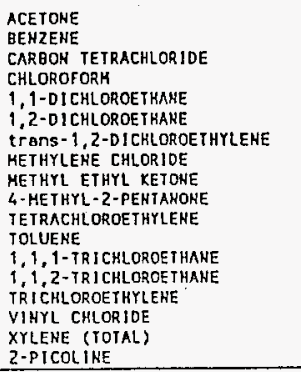 & $\begin{array}{l}100 \\
5 \\
5 \\
5 \\
5 \\
5 \\
5 \\
10 \\
100 \\
50 \\
5 \\
5 \\
5 \\
5 \\
5 \\
10 \\
5 \\
5 \\
\end{array}$ \\
\hline $\begin{array}{l}\text { VOLATILE ORGAHICS FOR GC/HS } \\
\text { APPEHOIX IX AODITIOHS } \\
\text { SH-846 } 8240\end{array}$ & 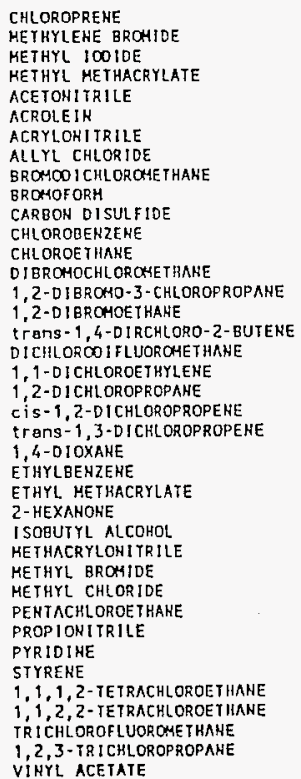 & $\begin{array}{l}5 \\
5 \\
5 \\
5 \\
100(8015) \\
5 \\
5 \\
100 \\
5 \\
5 \\
5 \\
5 \\
10 \\
5 \\
5 \\
5 \\
5 \\
5 \\
5 \\
5 \\
5 \\
5 \\
150(8015) \\
5 \\
5 \\
50 \\
50(8015) \\
5 \\
10 \\
10 \\
5 \\
5 \\
5 \\
5 \\
5 \\
5 \\
5 \\
5 \\
5 \\
\\
5\end{array}$ \\
\hline
\end{tabular}


WHC-SD-WM-WP-337, Rev. 0

Table 4-3. Appendix IX Analytical Methods and Constituent List for Groundwater Analyses. (sheet 3 of 4)

\begin{tabular}{|c|c|c|}
\hline ANALYIICAL METHOOS & CONST ITUENTS OF CONCERH & POL ppb \\
\hline $\begin{array}{l}\text { SEMIVOA ORGAHICS GC/MS } \\
\text { APPENDIX IV. LIST } \\
\text { SH-846 } 8270\end{array}$ & 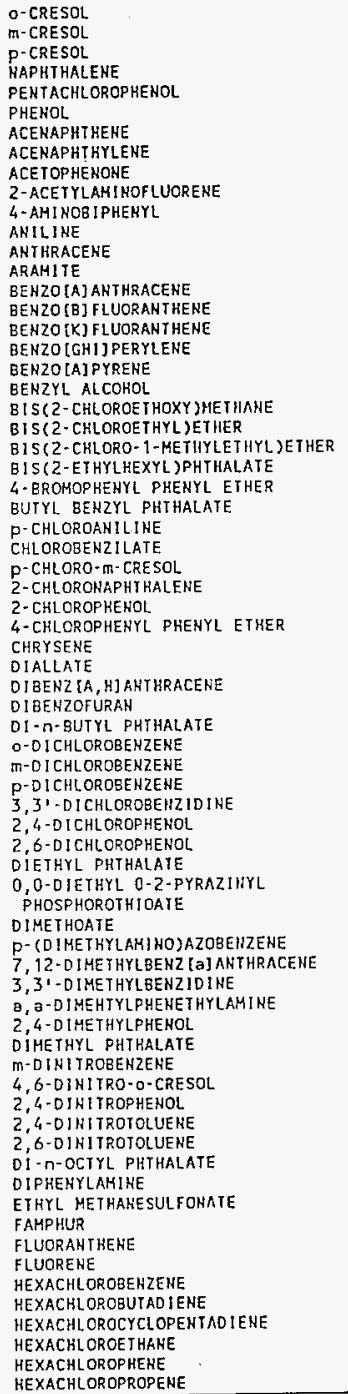 & $\begin{array}{l}10 \\
10 \\
10 \\
10 \\
50 \\
10 \\
10 \\
10 \\
10 \\
10 \\
10 \\
10 \\
10 \\
10 \\
10 \\
10 \\
10 \\
10 \\
10 \\
20 \\
10 \\
10 \\
10 \\
10 \\
10 \\
10 \\
20 \\
10 \\
20 \\
10 \\
10 \\
10 \\
10 \\
10 \\
10 \\
10 \\
10 \\
10 \\
10 \\
10 \\
20 \\
10 \\
10 \\
10 \\
10 \\
10 \\
10 \\
10 \\
10 \\
10 \\
10 \\
10 \\
10 \\
10 \\
50 \\
50 \\
10 \\
10 \\
10 \\
10 \\
10 \\
10 \\
10 \\
10 \\
10 \\
10 \\
10 \\
10 \\
10 \\
10 \\
\end{array}$ \\
\hline
\end{tabular}


Table 4-3. Appendix IX Analytical Methods and Constituent List for Groundwater Analyses. (sheet 4 of 4)

\begin{tabular}{|c|c|c|}
\hline AMALYTICAL METHOOS & COHSIITUENTS OF CONCERN & PQL ppb \\
\hline $\begin{array}{l}\text { SEHI-VOA ORGANICS GC/MS } \\
\text { APPENOIX IV LIST COHT. } \\
\text { SH- } 8468270 \\
\text {. }\end{array}$ & 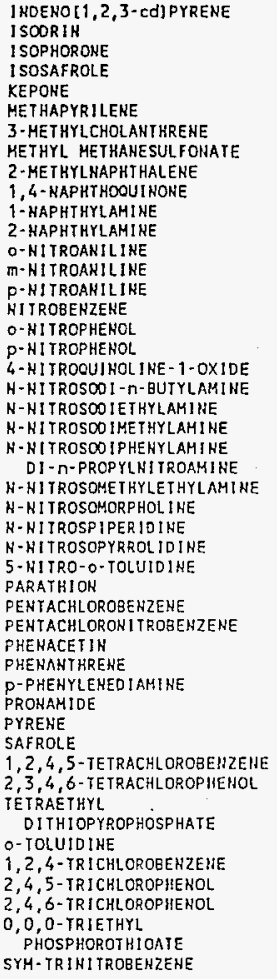 & $\begin{array}{l}10 \\
10 \\
10 \\
10 \\
10 \\
10 \\
10 \\
10 \\
10 \\
10 \\
10 \\
10 \\
50 \\
50 \\
50 \\
10 \\
50 \\
10 \\
10 \\
10 \\
10 \\
10 \\
10 \\
10 \\
10 \\
10 \\
10 \\
10 \\
10 \\
10 \\
10 \\
10 \\
10 \\
10 \\
10 \\
10 \\
10 \\
10 \\
10 \\
10 \\
10 \\
10 \\
10 \\
10 \\
10 \\
10 \\
10 \\
10 \\
10\end{array}$ \\
\hline $\begin{array}{l}\text { DIOXIN AND OIBENZOFURANS } \\
\text { SH-846 } 8280\end{array}$ & $\begin{array}{l}\text { PCODS } \\
\text { PCOFs } \\
2,3,7,8-1 \mathrm{CDO}\end{array}$ & $\begin{array}{l}0.01 \\
0.01 \\
0.005\end{array}$ \\
\hline
\end{tabular}


WHC-SD-WM-WP-337, Rev. 0

Table 4-4. Supplemental Constituent List for Groundwater Analyses. (After Caggiano and Goodwin 1991)

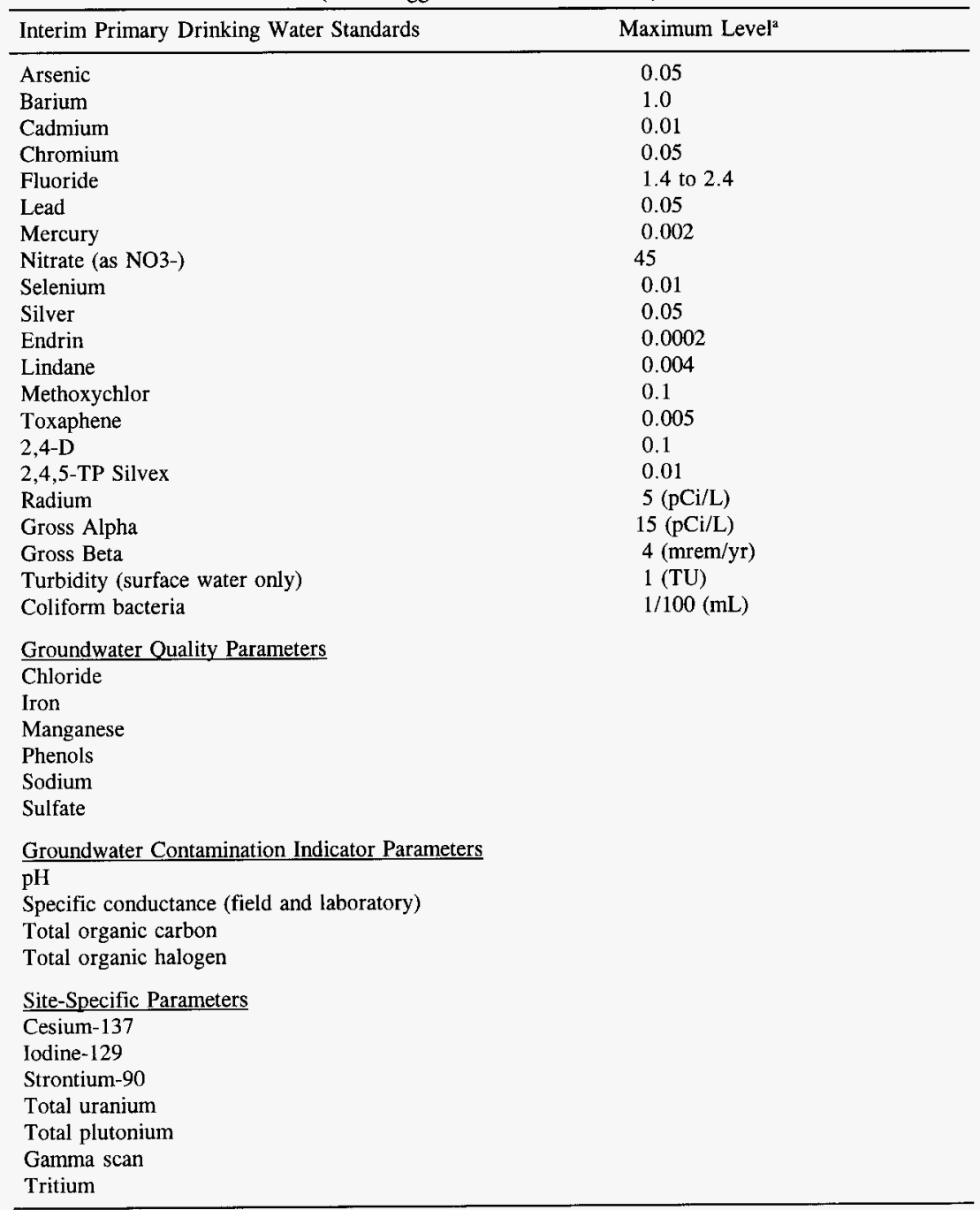

${ }^{a}$ Unless otherwise noted, concentrations are in $\mathrm{mg} / \mathrm{L}$. 
WHC-SD-WM-WP-337, Rev. 0

\subsection{GENERAL GUIDANCE DOCUMENTATION AND PROJECT MANAGEMENT}

All technical activities will be controlled, where applicable and appropriate, by one or more of the following: WACs, EPA guidance and regulations, DOE orders, WHC internal guidance, WHC Geosciences project plans, and ASTM standards. This guidance is cited in conjunction with the related activity(ies) and referenced in Section 7.0.

The project management structure and lines of communication for the subsurface investigation is represented by Figure 5-1. Field activities will be controlled by Geosciences and conducted by WHC field personnel or ICF KH. Groundwater and soil sampling and analysis will be performed or directed by Geosciences and controlled by the quality assurance project plan for groundwater monitoring activities (Stauffer and Washington 1995). Specific areas of responsibility, as they appear in Figure 5-1, are described below. One individual may have more than one role of responsibility. This management framework assumes that a similar structure will exist after October 1, 1996, when WHC responsibilities are turned over to the Project Hanford Management Contractor.

\subsection{TECHNICAL LEAD}

The responsibilities of the technical lead are to plan, authorize, and guide project work tasks to ensure the project is completed on schedule and within budget. The technical lead directs field team leader and ensures that the overall planning and performance of the subsurface characterization is technically sound, provides the needed information, and is within the scope of the work plan.

\subsection{QUALITY CONTROL AND QUALITY ASSURANCE ENGINEERS}

The quality control engineer is responsible for ensuring that tasks of this work plan are performed in accordance with the analytical methods and guidance stated by the work plan, and to advise the technical lead of deviations therefrom. The quality assurance engineer provides oversight of documentation and field activities, reviews the work plan before implementation of the tasks, and recommends corrective actions to the technical lead.

\subsection{FIELD TEAM LEADER}

The field team leader is responsible for directing field tasks and field personnel, including the project hydrologist, wellsite geologist, and project geophysicist.

\subsection{SITE SAFETY ENGINEER}

The site safety engineer ensures that overall health, safety procedures, and general precautions are adequate at the project site, and that these are observed by all field personnel. The site safety engineer has the authority to stop field activities until hazardous or unsafe conditions have been mitigated. 


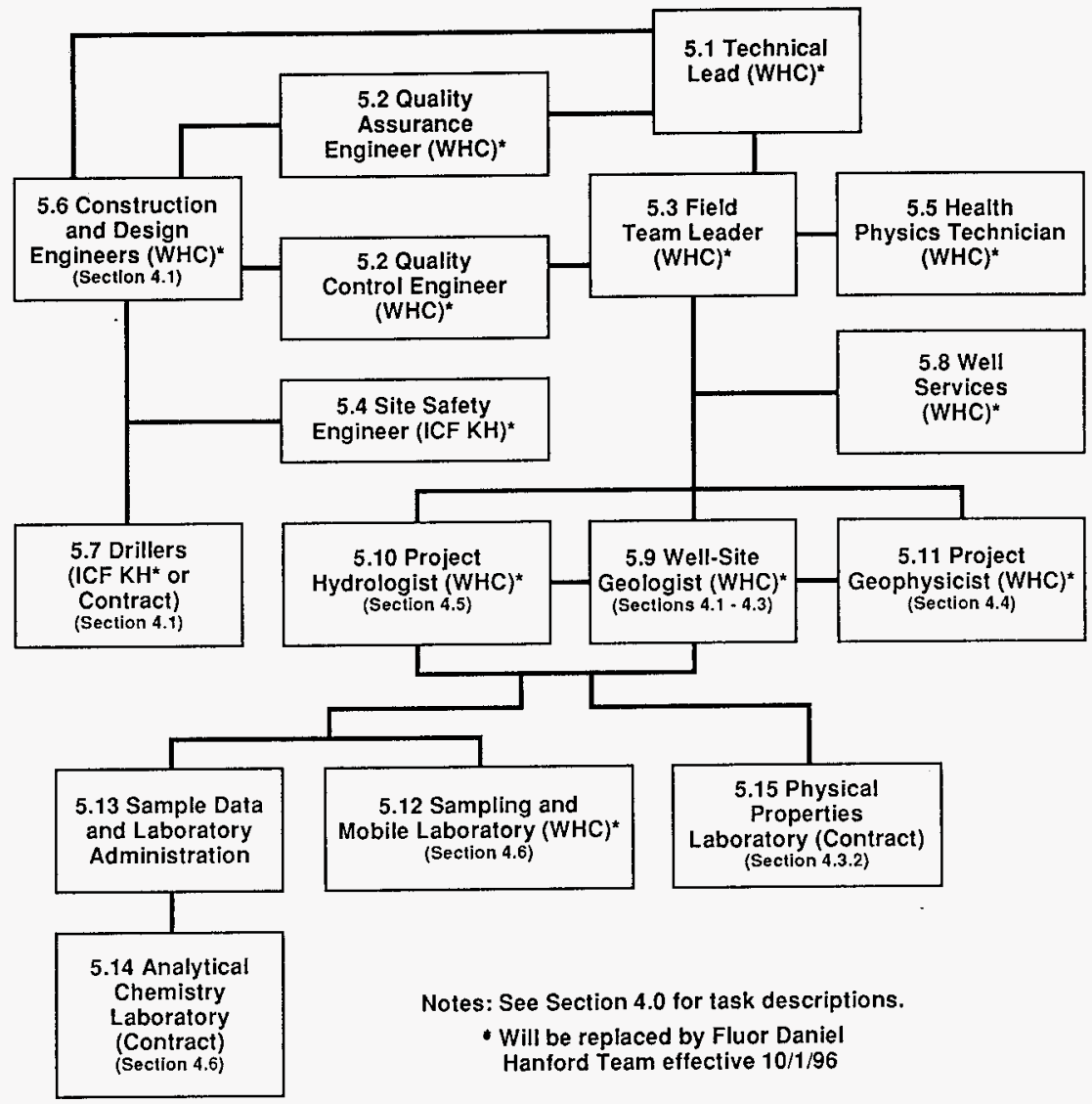

Figure 5-1. Project Management Structure and Lines of Communication. 


\subsection{HEALTH PHYSICS TECHNICIAN}

The health physics technician supports field work by screening all samples and exposed equipment (when appropriate) for radioactive contamination.

\subsection{CONSTRUCTION AND DESIGN ENGINEER}

The responsibility for pre-drilling preparations, procurement of the driller, and overall progress of the drilling aspects of the project rests with the WHC construction and design engineers. Pre-drilling preparations include; the HWOP (if appropriate), excavation permit, site surveys, Ecology start card, NEPA checklist, driller's scope(s) of work, purgewater determination, and waste management plans. The construction and design engineer also prepares the Letter of Instruction to the driller.

\subsection{DRILLERS}

ICF KH (or equivalent after October 1,1996 ) or a contracted drilling company will be responsible for construction of an access route (if needed), drilling pads, drilling of the borehole, and construction of the well to RCRA-compliant standards (see Section 4.1).

\subsection{WELL SERVICES}

Pump installation and well development will be completed by WHC well services. Well services will be directed by the field team leader to install the pump following in-well testing activities (see Sections 4.4 and 4.5). Flowmeter tests and dynamic testing will be implemented or aided by well services, under the direction of the project hydrologist.

\subsection{WELLSITE GEOLOGIST}

The wellsite geologist is responsible for all geologic logging activities associated with the subsurface characterization. The wellsite geologist will confer with the project hydrologist, Sampling and Mobile Laboratory staff, and field team leader to coordinate sampling for chemical and physical properties analyses.

\subsection{PROJECT HYDROLOGIST}

The project hydrologist is responsible for oversight of dynamic hydraulic testing, flowmeter surveys (see Section 4.5), and well development (see Section 4.1). The project hydrologist also confers with the wellsite geologist, field team leader, and technical lead for selection of sampling intervals. 
WHC-SD-WM-WP-337, Rev. 0

\subsection{PROJECT GEOPHYSICIST}

The project geophysicist is responsible for geophysical logging of the borehole in compliance with the work plan and applicable procedures (see Section 4.4). The project geophysicist also reduces and interprets collected geophysical data for submission to the technical lead.

\subsection{SAMPLING AND MOBILE LABORATORY}

The Sampling and Mobile Laboratory is responsible for collection, labeling, preservation, containment, packing, and transport of soil and groundwater samples. The Sampling and Mobile Laboratory works with the health physics technician and the field team leader to ensure that samples do not exceed radiation safety standards.

\subsection{SAMPLE DATA AND LABORATORY ADMINISTRATION}

The contract for laboratory analyses of groundwater samples is administered by SDLA. SDLA prepares the statement of work for the contracting laboratory, and serves as a quality assurance mechanism for analytical work submitted by Geosciences.

\subsection{ANALYTICAL CHEMISTRY LABORATORY}

Offsite contract laboratory(ies) will analyze soil and water chemistry samples provided by SDLA in accordance with the laboratory's quality assurance plan and guidance provided by SDLA and Geosciences. All analytical procedures are approved in advance of application by SDLA, and are further subject to Geosciences quality assurance surveillances and quality control audits.

\subsection{PHYSICAL PROPERTIES LABORATORY}

Tests for hydraulic properties and other physical soil parameters are contracted by Geosciences to a private laboratory. All analytical procedures are subject to WHC, ASA, and ASTM standards (see Section 4.3). Analytical results are submitted to the technical lead or designated representative.

\subsection{WORK PLAN CHANGES}

Unforeseen circumstances or aberrations arising in the field that require modifications in the work plan will be documented in the field logs, the GSFR, or nonconformance reports. If changes to the work plan result in modification of established WHC procedures, these changes will be documented as directed by EII 1.4 "Instruction Change Authorizations" (WHC 1988). Departures from laboratory procedures or other unusual laboratory occurrences will be documented in a Record of Disposition from SDLA (see Section 4.6). Departures are evaluated by Geosciences quality control. 
WHC-SD-WM-WP-337, Rev. 0

\subsection{PROJECT SCHEDULE}

The general timeline for the subsurface characterization project is shown in the schedule of Figure 6-1. The schedule assumes that approved budgets, organizations, and infrastructures required for the work to begin will be in place by October 1, 1996. Interruption of these provisions and services would delay the entire timeline or individual phases of the project 


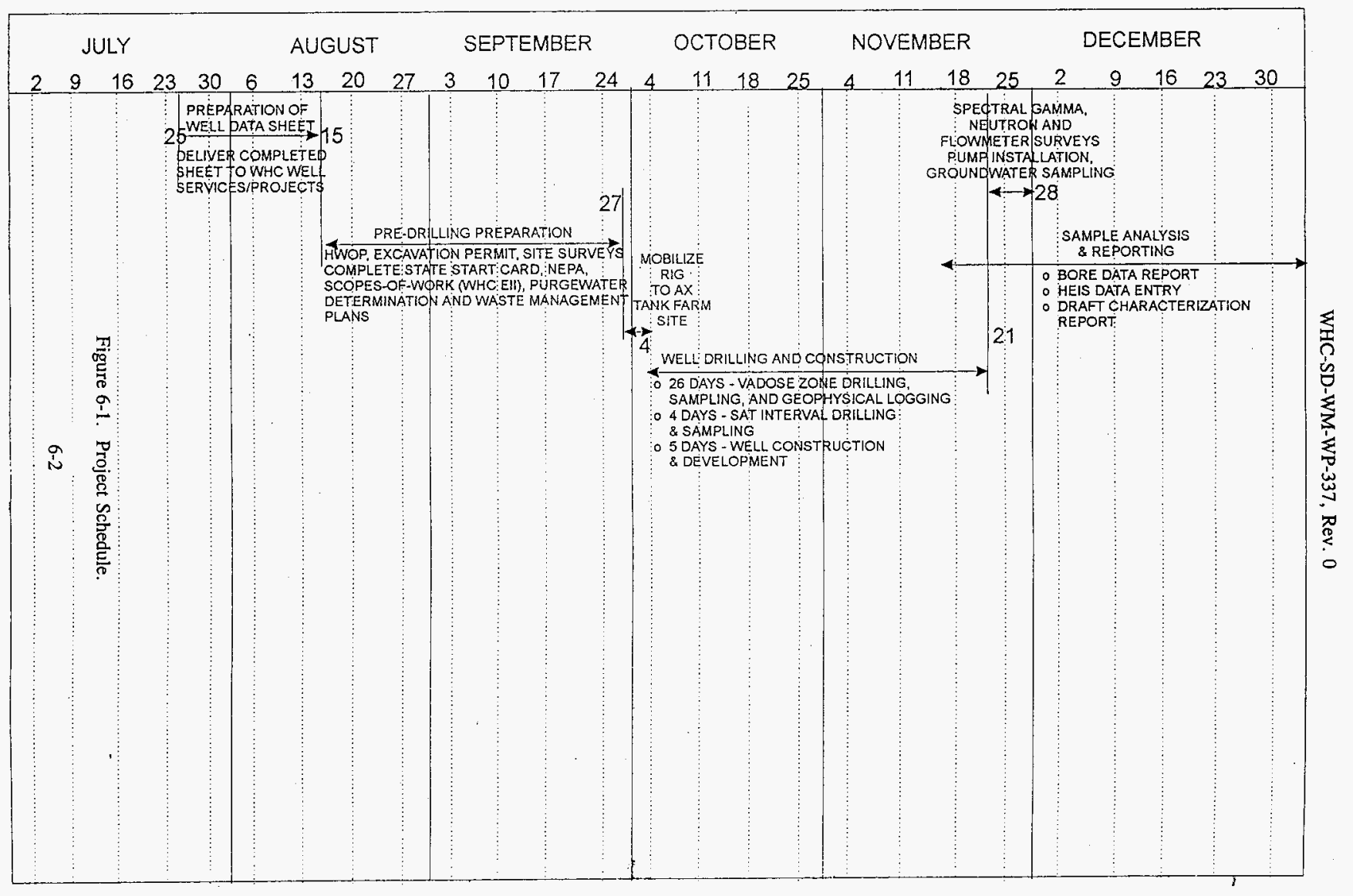




\subsection{REFERENCES}

40 CFR 265, "Interim Status Standards for Owners and Operators of Hazardous Waste Treatment, Storage, and Disposal Facilities," Code of Federal Regulations, as amended.

ASTM 1992, Annual Book of ASTM Standards, American Society of Testing and Materials, Philadelphia, Pennsylvania.

Baker, V. R., B. N. Bjornstad, A. J. Busacca, K. R. Fecht, E. P. Kiver, U. L. Moody, J. G. Rigby, O. F. Stradling, and A. M. Tallman, 1991, "Quaternary Geology of the Columbia Plateau," in Morrison, R. B., editor, Quaternary Nonglacial Geology; Conterminous United States. The Geology of North America, vol. K-2, Geological Society of America, Boulder, Colorado, p. 215-250.

Black, B. F., 1979, Clastic Dikes of the Pasco Basin, Southeastern Washington, RHO-BWI-C-64, Rockwell Hanford Operations, Richland, Washington.

Brevick, C. H., 1995, Historical Tank Content Estimate for the Northeast Quadrant of the Hanford 200 East Area, WHC-WM-ER-349, Rev. Oa, ICF Kaiser Hanford, Work Order ER4945, for Westinghouse Hanford Company, Richland, Washington.

Caggiano, J. A., and S. M. Goodwin, 1991, Interim Status Groundwater Monitoring Plan for the Single-Shell Tanks, WHC-SD-EN-AP-012, Rev. 1, Westinghouse Hanford Company, Richland, Washington.

Caggiano, J. A., 1996, "Single-Shell Tanks," in Annual Report for RCRA Groundwater Monitoring Projects at Hanford Site Facilities for 1995, DOE/RL-96-01, Rev. 0, U.S. Department of Energy, Richland Operations Office, Richland Washington.

Connelly, M. P., J. V. Borghese, C. D. Delaney, B. H. Ford, J. W. Lindberg, and S. J. Trent, 1992a, Hydrogeologic Model for the 200 East Groundwater Aggregate Area, WHC-SD-EN-TI-019, Rev. 0, Westinghouse Hanford Company, Richland, Washington.

Connelly, M. P., B. H. Ford, and J. V. Borghese, 1992b, Hydrogeologic Model for the 200 West Groundwater Aggregate Area, WHC-SD-EN-TI-014, Rev. 0, Westinghouse Hanford Company, Richland, Washington.

Davis, J. D. and C. D. Delaney, 1992, Site Characterization Work Plan -- 200 Areas Treated Effluent Disposal Basin, Project W-049H, WHC-SD-W049H-WP-001, Rev. 1, Westinghouse Hanford Company, Richland, Washington.

Delaney, C. D., K. A. Lindsey, and S. P. Reidel, 1991, Geology and Hydrology of the Hanford Site: A Standardized Text for Use in Westinghouse Hanford Company Documents and Reports, WHC-SD-ER-TI-0003, Rev. 0, Westinghouse Hanford Company, Richland, Washington.

DOE, 1988, Consultation Draft Site Characterization Plan: Office of Civilian Radioactive Waste Management, DOE/RW-0164, Vols. 1-9, U.S. Department of Energy, Washington, D.C. 
DOE-RL, 1995, Annual Report for RCRA Groundwater Monitoring Projects at Hanford Site Facilities for 1994, DOE/RL-94-136, U.S. Department of Energy, Richland, Washington.

DOE-RL, 1996a, Annual Report for RCRA Groundwater Monitoring at Hanford Site Facilities for 1995, DOE/RL-96-01, Rev. 0, U.S. Department of Energy, Richland, Washington.

DOE-RL, 1996b, Single-Shell Tank Closure Work Plan, DOE/RL-89-16, Rev. 1, U.S. Department of Energy, Richland Operations Office, Richland, Washington.

Ecology, DOE, and EPA, 1994, Hanford Federal Facility Agreement and Consent Order, Washington State Department of Ecology, U.S. Department of Energy, and U.S. Environmental Protection Agency, Olympia, Washington.

Ecology, 1994, Minimum Standards for Construction and Maintenance of Water Wells, WAC 173-160, Washington State Department of Ecology, Olympia, Washington.

EPA, 1979, Methods for Chemical Analysis for Water and Wastes, EPA-600/4-79-020,

U.S. Environmental Protection Agency, Washington, D.C.

EPA, 1986, "National Primary Drinking Water Regulations," Title 40, Code of Federal Regulations, Part 264, Appendix IX as amended, U. S. Environmental Protection Agency, Washington, D.C.

EPA, 1989, Statistical Analysis of Groundwater Monitoring Data at RCRA Facilities - Interim Final Guidance, EPA/530-SW-89-026, U.S. Environmental Protection Agency, Washington, D.C.

EPA, 1990, "Test Methods for Evaluation of Solid Waste, Physical/Chemical Methods," EPA

Publication SW-846 Second Edition (1982) as amended by Update I (April 1984) and Update II (April 1985) together with 47 analytical test methods contained in Third Edition (November 1986), its Revision I (December 1987) and Technical Corrections (May 1990).

EPA, 1992, Statistical Analysis of Groundwater Monitoring Data at RCRA Facilities, Draft Addendum to Interim Final Guidance, EPA/530-R-93-003, U.S. Environmental Protection Agency, Washington, D.C.

Ford, B. H., 1993, Groundwater Field Characterization Report for the 200 Area Aggregate Management Area Study, WHC-SD-EN-TI-020, Rev. 0, Westinghouse Hanford Company, Richland, Washington.

Goldstrand, P. M., 1984, Generalized Geology of the 241-AP Tank Farm, RHO-RE-EV-31, Rockwell Hanford Operations, Richland, Washington.

Gephart, R. E., R. C. Arnett, R. G. Baca, L. S. Leonhart, and F. A. Spane, Jr., 1979, Hydrologic Studies Within the Columbia Plateau, Washington: An Integration of Current Knowledge, RHO-BWI-ST-5, Rockwell Hanford Operations, Richland, Washington.

Graham, M. J., M. D. Hall, S. R. Strait, and W. R. Brown, 1981, Hydrology of the Separations Area, RHO-ST-42, Rockwell Hanford Operations, Richland, Washington. 
Graham, M. J., G. V. Last, and K. R. Fecht, 1984, An Assessment of Aquifer Intercommunication in the B Pond-Gable Mountain Pond Area of the Hanford Site, RHO-RE-ST-12, Rockwell Hanford Operations, Richland, Washington.

Hanlon, B. M., 1995, Tank Farm Surveillance and Waste Status Summary Report for February 28, 1995, WHC-EP-0182-83, Westinghouse Hanford Company, Richland, Washington.

Hanlon, B. M., 1996, Tank Farm Surveillance and Waste Status Summary Report for May, 1996, WHC-EP-0182-99, Westinghouse Hanford Company, Richland, Washington.

Horton, D. G., 1996, "Fiscal Year 1996 Resource Conservation and Recovery Act and Operational Monitoring Laboratory Analysis Statement of Work," Westinghouse Hanford Company Internal Memo 8H200-96-029, dated July 2, 1996, Westinghouse Hanford Company, Richland, Washington.

Khaleel, R. and E. J. Freeman, 1995, Variability and Scaling of Hydraulic Properties for 200 Area Soils, Hanford Site, WHC-EP-0883, Westinghouse Hanford Company, Richland, Washington.

Klute, A., 1986, "Methods of Soil Analysis," Second Edition, Part 1, "Physical and Mineralogical Methods," American Society of Agronomy, Inc., Soil Science Society of America, Inc., Madison, Wisconsin.

Knutson, B. J., 1995, TWRS Mission Analysis, WHC-SD-WM-MAR-008, Rev. 0, Westinghouse Hanford Company, Richland, Washington.

Law, A. G., J. A. Serkowski, and A. L. Schatz, 1987, Results of the Separations Area Ground-Water Monitoring Network for 1986, RHO-RE-SR-87-24 P, Rockwell Hanford Operations, Richland, Washington.

Lindberg, J. W., J. V. Borghese, B. N. Bjornstad, and M. P. Connelly, 1992, Geology and Aquifer Characteristics of the Grout Treatment Facility, WHC-SD-EN-TI-071, Rev. 0, Westinghouse Hanford Company, Richland, Washington.

Lindsey, K. A., 1991, Revised Stratigraphy for the Ringold Formation, Hanford Site, South-Central Washington, WHC-SD-EN-EE-004, 12 p, Westinghouse Hanford Company, Richland, Washington.

Lindsey, K. A., B. N. Bjornstad, J. W. Lindberg, and K. M. Hoffman, 1992, Geologic Setting of the 200 East Area: An Update, WHC-SD-EN-TI-012, Westinghouse Hanford Company, Richland, Washington.

Lindsey, K. A., 1995, Miocene- to Pliocene-age Suprabasalt Sediments of the Hanford Site, SouthCentral Washington, BHI-00184, 42 p., 4 Appendices, Bechtel Hanford, Inc., Richland, Washington.

Lindsey, K. A. and A. G. Law, 1993, Geohydrologic Setting, Flow, and Transport Parameters for the Single-Shell Tank Farms, WHC Internal Memo 81231-93-060, Westinghouse Hanford Company, Richland, Washington. 
Lindsey, K. A, S. P. Reidel, K. R. Fecht, J. L. Slate, A. G. Law, and A. M. Tallman, 1994a, "Geohydrologic Setting of the Hanford Site, South-Central Washington, In Swanson, D. A. and R. A. Haugerud, editors, Geologic Field Trips of the Pacific Northwest: 1994 Geological Society of America Annual Meeting, Dept. of Geological Sciences, University of Washington, Seattle, Washington, p. 1C-1 through 1C-16.

Lindsey, K. A., J. L. Slate, G. K. Jaeger, K. J. Swett, and R. B. Mercer, 1994b, Geologic Setting of the Low-Level Burial Grounds, WHC-SD-EN-TI-290, Rev. 0, 82 p., Westinghouse Hanford Company, Richland, Washington.

PNL, 1994, Hanford Site Groundwater Monitoring for 1993, PNNL-10082, Pacific Northwest National Laboratory, Richland, Washington.

Price, W. H. and K. R. Fecht, 1976, Geology of the 241-AX Tank Farm, ARH-LD-128, Atlantic Richfield Hanford Company, Richland, Washington.

Reidel, S. P., K. A. Lindsey, and K. R. Fecht, 1992, Field Trip Guide to the Hanford Site, WHC-MR-0391, 49 p., Westinghouse Hanford Company, Richland, Washington.

Reidel, S. P., N. P. Campbell, K. R. Fecht, and K. A. Lindsey, 1994, "Late Cenozoic Structure and Stratigraphy of South-Central Washington," in Regional Geology of Washington State, R. Lasmais and E. S. Cheney (eds.), Washington Division of Geology and Earth Resources Bulletin 80, Olympia, Washington.

Reynolds, K. D. and K. A. Lindsey, 1994, Instructions for Borehole Sampling, WHC-SD-EN-AP181, Rev. 0, Westinghouse Hanford Company, Richland, Washington.

Reynolds, K. D., 1996, Generic Well Specifications, WHC-S-014, Westinghouse Hanford Company, Richland, Washington.

Rodenhizer, D. G., 1987, Hanford Waste Tank Sluicing History, WM-TI-302, Westinghouse Hanford Company, Richland, Washington.

Stauffer, M. and T. X. Washington, 1995, Quality Assurance Project Plan for Groundwater Monitoring Activities Managed by Westinghouse Hanford Company, WHC-SD-EN-QAPP001, Rev. 3, Westinghouse Hanford Company, Richland, Washington.

Van Vleet, R. J., 1993, Radionuclide and Chemical Inventories for the Single-Shell Tanks, WHC-SD-WM-TI-565, Rev. 1, Westinghouse Hanford Company, Richland, Washington.

Welty, R. K., 1988, Waste Storage Tank Status and Leak Detection Criteria, WHC-SD-WM-TI-356, Westinghouse Hanford Company, Richland, Washington.

WHC, 1988, Environmental Investigations and Site Characterization Manual, WHC-CM-7-7, Vol. 1, Westinghouse Hanford Company, Richland, Washington.

WHC, 1992a, Environmental Engineering and Geotechnology Function Procedures, WHC-CM-7-8, Westinghouse Hanford Company, Richland, Washington. 


\section{WHC-SD-WM-WP-337, Rev. 0}

WHC, 1992b, Geotechnical Engineering Procedures Manual, WHC-IP-0635, Vols. 1 \& 2, Westinghouse Hanford Company, Richland, Washington.

WHC, 1994, Sampling and Mobile Laboratories Procedure Manual, WHC-IP-1127, Westinghouse Hanford Company, Richland, Washington. 
WHC-SD-WM-WP-337, Rev. 0

This page intentionally left blank. 